\title{
Tectonic and lithological controls on fluvial landscape development in central-eastern Portugal: Insights from long profile tributary stream analyses
}

\author{
António A. Martins ${ }^{\text {a }}$, João Cabral ${ }^{\text {b }}$, Pedro P. Cunha ${ }^{\text {c,* }}$, Martin Stokes ${ }^{\text {d }}$, José Borges ${ }^{\text {e }}$, \\ Bento Caldeira ${ }^{\mathrm{e}}, \mathrm{A}$. Cardoso Martins ${ }^{\mathrm{f}}$ \\ a Instituto de Ciências da Terra (ICT), Departamento de Geociências, Universidade de Évora, Portugal \\ b Instituto Dom Luiz, Departamento de Geologia, Faculdade de Ciências, Universidade de Lisboa, Lisboa, Portugal \\ c MARE - Marine and Environmental Sciences Centre, Department of Earth Sciences, Universidade de Coimbra, Coimbra, Portugal \\ ' School of Geography, Earth and Environmental Sciences, Plymouth University, UK \\ e Instituto de Ciências da Terra (ICT), Departamento de Física, Universidade de Évora, Portugal \\ ${ }^{\mathrm{f}}$ Nova School of Business and Economics, Lisboa, Portugal
}

\section{A R T I C L E I N F O}

\section{Article history:}

Received 1 May 2016

Received in revised form 1 October 2016

Accepted 7 October 2016

Available online 11 October 2016

\section{Keywords:}

Knickpoint/knickzone

Equilibrium long profile

Fluvial incision

Uplift

\begin{abstract}
A B S T R A C T
This study examines the long profiles of tributaries of the Tagus and Zêzere rivers in Portugal (West Iberia) in order to provide new insights into patterns, timing, and controls on drainage development during the Quaternary incision stage. The studied streams are incised into a relict culminant fluvial surface, abandoned at the beginning of the incision stage. The streams flow through a landscape with bedrock variations in lithology (mainly granites and metasediments) and faulted blocks with distinct uplift rates. The long profiles of the analyzed streams record an older transitory knickpoint/knickzone separating (1) an upstream relict graded profile, with lower steepness and higher concavity, that reflects a long period of quasi-equilibrium conditions reached after the beginning of the incision stage, and (2) a downstream rejuvenated long profile, with steeper gradient and lower concavity, particularly for the final reach, which is often convex. The rejuvenated reaches testify to the upstream propagation of several incision waves, interpreted as the response of each stream to increasing crustal uplift and prolonged periods of base-level lowering by the trunk drainages, coeval with low sea level conditions. The morphological configurations of the long profiles enabled spatial and relative temporal patterns of incisions to be quantified. The incision values of streams flowing on the Portuguese Central Range (PCR; ca. 380-150 m) are variable but generally higher than the incision values of streams flowing on the adjacent South Portugal Planation Surface (SPPS; ca. 220-110 m), corroborating differential uplift of the PCR relative to the SPPS. Owing to the fact that the relict graded profiles can be correlated with the Tagus River T1 terrace (1.1-0.9 My) present in the study area, incision rates can be estimated (1) for the streams located in the PCR, $0.38-0.15 \mathrm{~m} / \mathrm{ky}$ and (2) for the streams flowing on the SPPS, $0.22-0.12 \mathrm{~m} / \mathrm{ky}$. The differential uplift inferred in the study area supports the neotectonic activity of the bordering faults, as proposed in previous studies based upon other geological evidence.
\end{abstract}

(C) 2016 Elsevier B.V. All rights reserved.

\section{Introduction}

The Portuguese territory, positioned along the western Atlantic border of Iberia, presents a complex geodynamic setting characterized by interplay between (i) passive margin Atlantic ridge push effects and (ii) interplate interactions related to NW-SE convergence of Eurasia

\footnotetext{
* Corresponding author at: Departamento de Ciências da Terra, Rua Sílvio Lima, Universidade de Coimbra - Pólo II, 3030-790 Coimbra, Portugal.

E-mail addresses: aam@uevora.pt (A.A. Martins), jcabral@fc.ul.pt (J. Cabral), pcunha@dct.uc.pt (P.P.Cunha), M.Stokes@plymouth.ac.uk (M. Stokes), jborges@uevora.pt (J. Borges), bafcc@uevora.pt (B. Caldeira), amcmartins93@gmail.com (A.C. Martins).
}

and Africa (Nubia; at 4-5 mm/y; Calais et al., 2003; Nocquet and Calais, 2004; Cloetingh et al., 2005; Fernandes et al., 2007). The resulting stress field produces long wavelength vertical movements (uplift/subsidence) as well as fault movements, which together accommodate the tectonically induced finite strain. This neotectonic activity impacts on the regional landscape, acting upon an inherited morphology that has evolved through the Cenozoic (Cabral and Ribeiro, 1993; Ribeiro et al., 1996; Cloetingh et al., 2002, 2005; De Vicente et al., 2007, 2008, 2011; Cabral, 2012).

The landscape of mainland Portugal is characterized by a high average elevation, dominated by the northern Meseta (a plateau at an altitude ranging from ca. 650 to $700 \mathrm{~m}$ ). It also presents a succession of 
NE-SW trending mountain ranges, with altitudes of up to ca. $2000 \mathrm{~m}$, and intervening topographic lows corresponding to sedimentary basins at altitudes of ca. 600 to $100 \mathrm{~m}$. These regional scale topographic variations trend normal to the present-day intraplate compressional stress trajectories, having been interpreted as the result of lithospheric buckling coupled with reverse faulting (Cloetingh et al., 2002, 2005; Vegas, 2005; De Vicente et al., 2008). The morphology is largely dominated by erosional plateaus elevated to different heights. These are cut onto metasedimentary rocks and granites of the Neoproterozoic and Palaeozoic Hesperian Massif, as well as onto Mesozoic and Cenozoic sedimentary basin fill successions. Relief distribution and hypsometry (43\% of the landscape area is below $200 \mathrm{~m}, 30 \%$ above $400 \mathrm{~m}$, and only $0.5 \%$ above $1200 \mathrm{~m}$ altitude) reflects the amplitude of the vertical movements. Some $95 \%$ of the landscape areas above $400 \mathrm{~m}$ are located in the northern and central parts of the country. In the central region, uplift was the greatest, raising the Portuguese Central Range (PCR) to a maximum altitude of $1993 \mathrm{~m}$.

A broad regional scale characterization of the Quaternary vertical movements in mainland Portugal has been tentatively performed through the use of geological and geomorphological markers. Sea level markers in modern coastal regions include a regional Pliocene wavecut platform dated as ca. 3.70-3.61 My (Diniz et al., 2016) overlain by a sedimentary unit that has the top surface (the Culminant Fluvial Surface) with a probable age of $1.8 \mathrm{My}$ (Cunha et al., 2016) and some dated Pleistocene marine terraces (e.g., Ramos et al., 2012; Carvalhido et al., 2014). Inland, terrestrial land surface markers include also the Culminant Fluvial Surface (CFS) as well as fluvial terraces along major river valleys. When using the CFS as a geomorphic marker for the last ca. 1.8 My, the estimated long-term uplift rate varies from 0.05 to $0.2 \mathrm{~mm} / \mathrm{y}$, but is generally higher inland relative to coastal areas. The highest estimated uplift rates, of ca. $0.2 \mathrm{~mm} / \mathrm{y}$, relate to the NE part of Portugal and the PCR (Cunha et al., 2005, 2008, 2012, 2016; Martins et al., 2009; Cabral, 2012).

River terraces provide useful insights into the dominant forcing mechanisms for fluvial systems: tectonics, climate, and sea level. However, terrace records are often spatially and temporally fragmented and where preserved are more likely to be associated with higher order trunk river systems. Lower order tributary streams commonly lack terrace records because sediment storage space is limited and the steeper gradients result in higher stream power, which tends to promote sediment erosion and transport. Thus, the valley floors of tributary streams are often dominated by bedrock reaches or, at the very least, by a thin transitory cover of alluvial material. In such settings, the long profile of the tributary stream is often the only geomorphological information that can be used to provide insights into the long-term fluvial landscape history.

In this study we use fluvial drainage analysis, namely river long profiles and slope-drainage area analyses to characterize the Quaternary uplift evolution in a study area located in the PCR and its adjacent South Portugal Planation Surface (SPPS), where relatively high uplift rates and significant differential vertical movements between faultbounded crustal blocks have been documented.

For this we used a section of the Tagus River that flows across the SPPS adjacent to the SE piedmont of the PCR, and the related drainage network, including one major tributary (the Zêzere River) that flows through the PCR (Figs. 1 and 2). The Tagus River was chosen because of its size (longest river in Iberia, with a length of $1040 \mathrm{~km}$ and the third largest drainage area, of $81,000 \mathrm{~km}^{2}$ ), thus assuring a relatively fast response to external forcing mechanisms and providing a relatively stable regional base level, and because of its location in the regional morphotectonic framework. The targeted tributaries are located in the main relief of the PCR. Their long profiles and knickpoints are used to identify differential uplift between uplifted blocks and local fault interactions as components of the regional long-term uplift rate.

Three main objectives are considered: (i) to estimate the magnitude of fluvial incision post-dating a generalized steady phase on landscape evolution and consequently formation of a graded longitudinal profile on drainage; (ii) to use the fluvial incision as a proxy for uplift; (iii) to analyze the stream profiles and drainage basins to calculate the normalized steepness index $k_{s n}$ (Wobus et al., 2006), which is considered a sensitive parameter to tectonics, in order to detect differential uplift between crustal blocks and to infer neotectonic activity of bordering faults.

\section{Geological and morphotectonic setting}

The drainage network of the study region flows mostly on the Iberian Hesperian Massif, consisting predominantly of slates and metagreywackes of Neoproterozoic to Cambrian age intensely folded by the Variscan Orogeny. Ordovician to Devonian quartzites and slates occur at the core of synclines exposed along narrow bands trending NW-SE, following the regional Variscan fabric. Also outcropping are some pre- and late to post-orogenic granite intrusions (Fig. 2). From the end of the Variscan Orogeny in the late Carboniferous and continuing to the early Cenozoic, the basement was eroded to a broad planation surface (the Iberian Meseta), above which the Ordovician quartzites and slates form elongated 'Appalachian' style resistant reliefs, but also occurring scattered inselbergs in granite areas (Cunha, 1992; Cunha and Pena dos Reis, 1995; Dinis et al., 2008).

During the Cenozoic, this broad planation surface was deformed into topographic highs (pop-ups) and lows (pop-downs; these constituting sedimentary basins) as a result of the Alpine interplate compression (Ribeiro, 1984; Ribeiro et al., 1990; De Vicente et al., 2007, 2011; Pais et al., 2012). The Alpine compression generated the NE-SW trending PCR, corresponding to a complex pop-up structure bounded by major NE-SW reverse faults, though slightly asymmetric, with one major fault (Seia-Lousã fault, SLf) on the NW side and deformation distributed across several faults on the SE side (including the Sobreira Formosa fault, SFf; e.g., Ribeiro et al., 1990; Sequeira et al., 1997; Figs. 2 and 3).

Tectonically controlled piedmont depressions occur on the SE side of the PCR, namely the Sarzedas and the Ródão-Idanha a Nova-Moraleja (Fig. 2), displacing the SPPS (Ribeiro, 1942; Cunha, 1987, 1992; Dias and Cabral, 1989; Vegas, 2006). These are bounded to the NW by the Sobreira Formosa and Rapoula faults (SFf and Rapf) and by the Ponsul fault (Pf), respectively (Fig. 2), corresponding to subbasins of the wider Lower Tagus Cenozoic basin. The sedimentary infill of this basin consists predominantly of alluvial fan gravelly sandstones (probably Eocene) and fluvial sands and silts (Miocene), overlain by coarser lithoclastic (slates and metagreywackes clasts) alluvial fan deposits attributed to the latest Miocene and Zanclean. These coarser deposits have been correlated to the main phases of mountain building (Cunha, 1992, 1996), thus indicating that major uplifting of the PCR occurred in the upper Neogene. The uppermost sedimentary unit, represented by the siliciclastic Falagueira Formation, has been considered of Piacenzian to Gelasian in age ( 3.65 to $1.8 \mathrm{My}$ ) and interpreted to record the capture of an Iberian endorheic drainage (Madrid Cenozoic basin) by a westward-draining Atlantic fluvial drainage (Lower Tagus basin) (Cunha, 1992, 1996; Cunha et al., 1993, 2005, 2008, 2012; Pérez-González, 1994; Pais et al., 2012).

The study area partially covers the southwestern part of the PCR and the adjacent SPPS, across which the Tagus River flows in an entrenched valley. In this area, the Falagueira Formation is generally 10-20 m thick, always at the top of interfluves, associated with the coeval relict Culminant Fluvial Surface (expressed as a very large paleovalley) preserved in remote areas away from the modern Tagus channel, and in minor sheltered areas of the PCR (Fig. 3). The geomorphic and sedimentary characteristics indicate that the ancestral Tagus River flowed on a laterally extensive low gradient alluvial plain. This period of the drainage history marks the final stage of sedimentary infilling in the Lower Tagus basin prior to the onset of the fluvial incision stage, which probably began just after the Gelasian (1.8 My; Cunha et al., 2012, 2016; Rosina et al., 2014). 


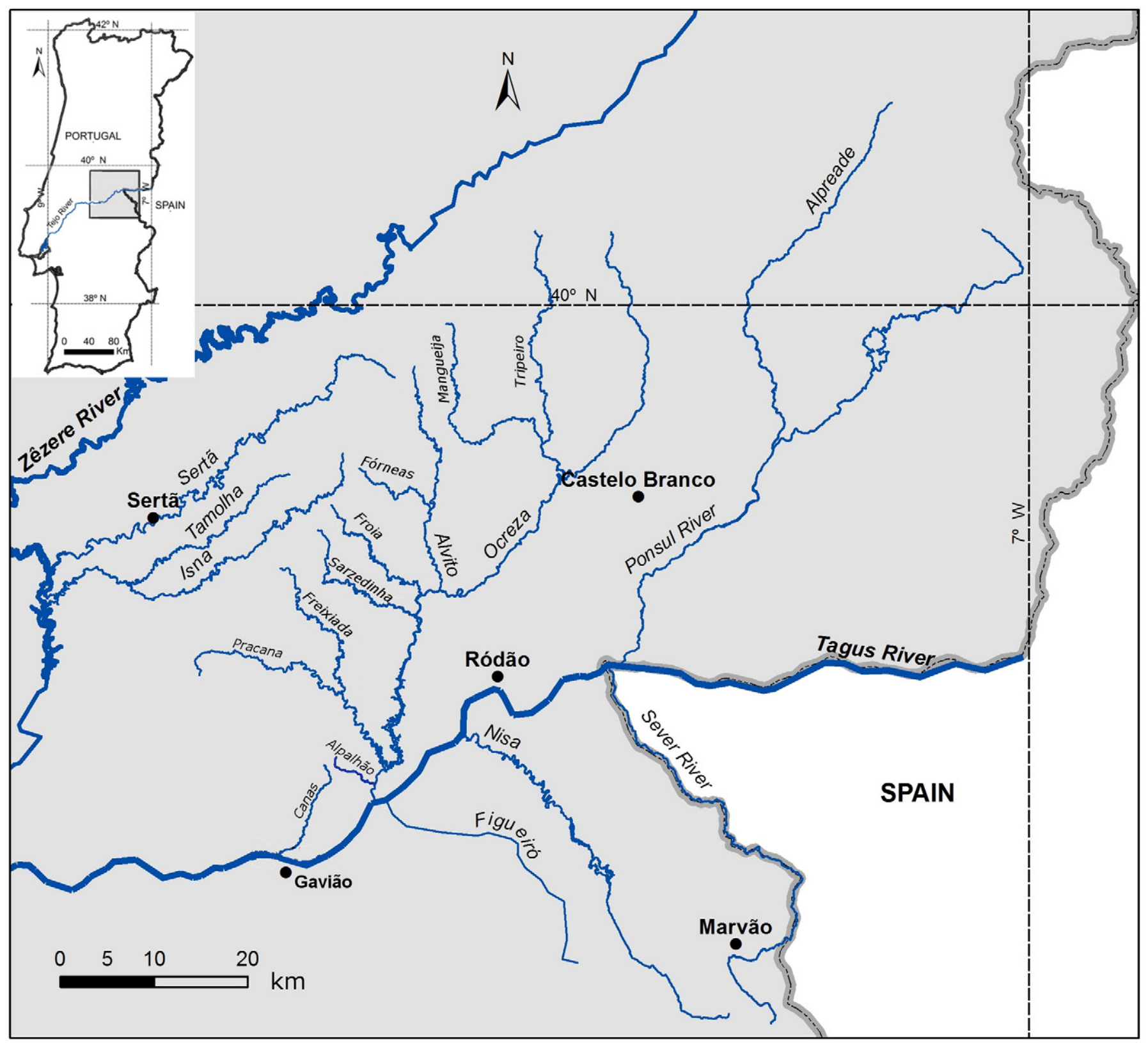

Fig. 1. Geographical setting of the study area (inset) and identification of the rivers and streams analyzed in this paper.

The SE boundary fault of the PCR (Sobreira Formosa fault, SFf) is crossed by tributary streams of the Tagus River flowing southward from the mountain to the adjacent lower SPPS (Fig. 2). Within the study area, however, other major tributaries (the Zêzere and Sertã rivers) flow along low-lying intra-montane corridors trending longitudinally to the mountain range, which are interpreted as tectonic depressions located between uplifted blocks (Daveau et al., 19851986), in a sequence of reverse fault bounded pop-up/pop-down structures similar to those proposed by De Vicente et al. (2007) for the Gredos sector of the SCS.

Besides the ENE-WSW longitudinal faults, there are a limited number of WNW-ESE transverse faults that cross the mountainous system, such as the Sertã fault (Sf) in the southwestern part (Fig. 2). The kinematic of the Sf is poorly constrained, but geomorphic evidence suggests a dominant right lateral strike-slip movement with a subsidiary vertical movement component corresponding to some uplifting of the southern block relative to the northern block. The Sertã, Isna, and Tamolha streams flow across the uplifted southern block possibly by an antecedent process (Daveau, 1985; Fig. 3).

Slip rates are estimated for two main regional ENE-WSW reverse faults based upon estimated offsets and the probable age of the Culminant Fluvial Surface, namely a slip-rate of 0.14 to $0.19 \mathrm{~mm} / \mathrm{y}$ for the Seia-Lousã fault (northern boundary fault of the PCR) and of 0.04 to $0.07 \mathrm{~mm} / \mathrm{y}$ for the Ponsul fault (southern boundary fault of the PCR) in the last $1.8 \mathrm{My}$. These slip rates fall in the range of 0.005 to $0.3-0.5 \mathrm{~mm} / \mathrm{y}$ that has been inferred for the active faults in Portugal mainland corresponding mostly to low activity rates and thus evidencing the dominance of slow fault movement (Cabral, 1995, 2012).

In the study area, the upstream section of Tagus River tributaries, including the Zêzere River, display long profiles with a smooth concaveup shape. This shape represents a steady state, or dynamic equilibrium profile, graded to an older and more elevated base level than the present. As stated, in these upper reaches the drainage is slightly inset into 


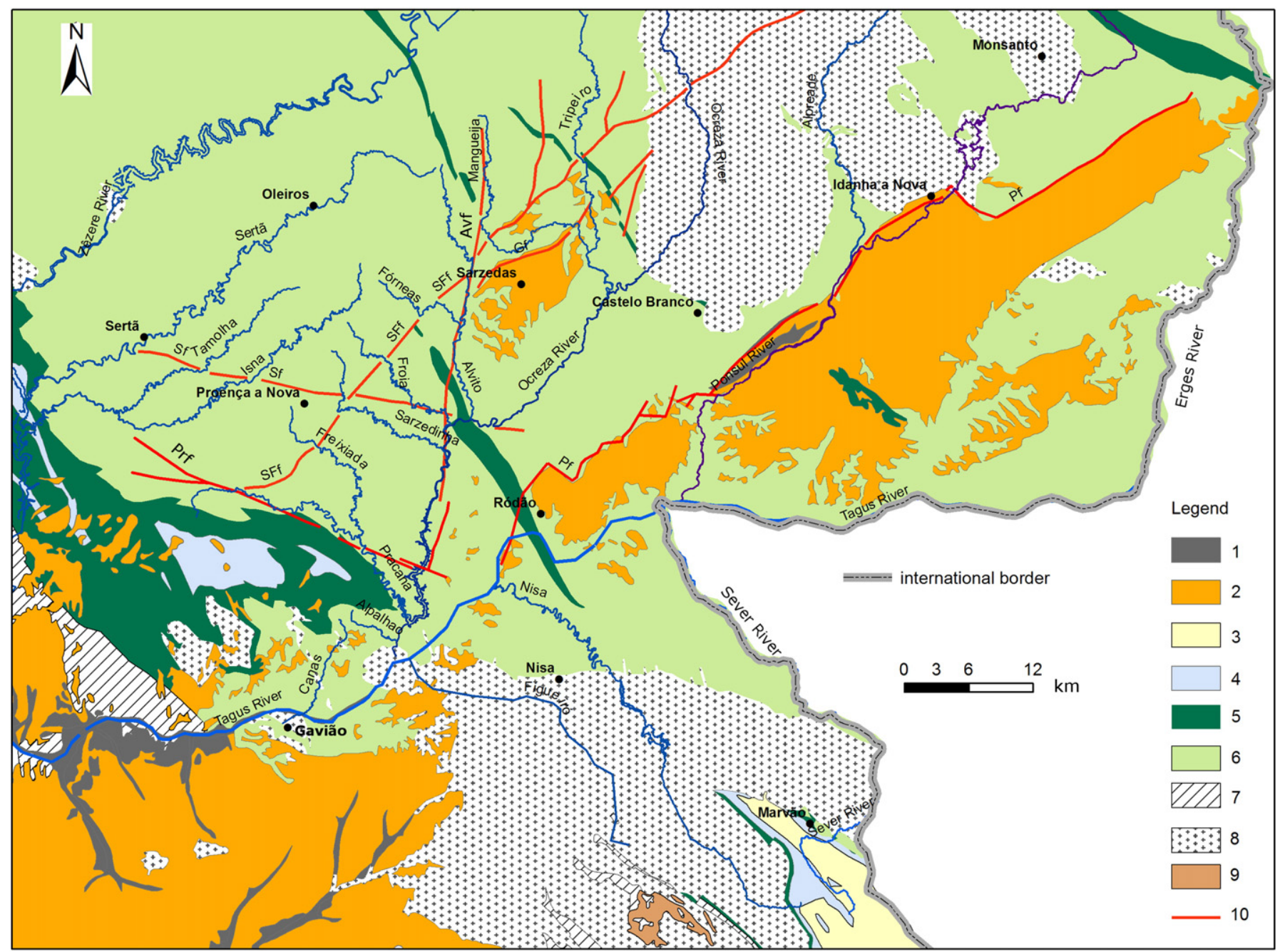

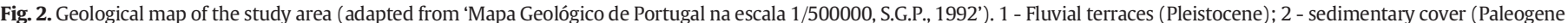

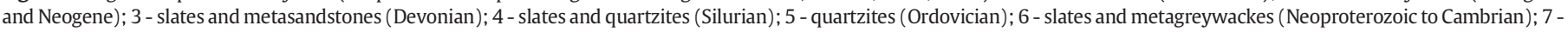

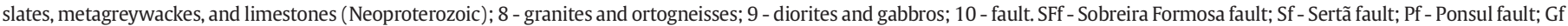
- Grade fault. The SFf constitutes the border between the PCR (at NW) and the SPPS (at SE).

a culminant rolling topography, interpreted as a fluvial landscape with a probable age of Piacenzian to Gelazian age (ca. 3.65 to $1.8 \mathrm{My}$ ).

The graded upstream relict profiles link to rejuvenated downstream reaches via oversteepened segments that mark the upstream limit of an incision wave. The transition to the oversteepened segments corresponds to transitory knickpoints or knickzones developed owing to a rate change in forcing (increase in river energy). In each channel, the knickpoint/zone has migrated upstream and incised the valley floor of the relict profile, leaving only short reaches in the headwaters not yet affected by the incision wave. In the main tributaries, the incision has left behind a perched bedrock bench feature, akin to a strath terrace, which can be used to pinpoint the location of knickpoints/zones by tracing the benches upstream until they merge with the relict bedrock channel.

\section{Methodology}

In an area that is being subjected to continuous uplift (i.e, the study region), the amount of long-term river incision (comprising several eustatic and climatic short-term cycles) can be considered a proxy for uplift. At the stream mouth/confluence, the magnitude of incision is at a maximum and it encompasses all of the successive incision phases since rejuvenation of the drainage network has occurred (Kirby and Whipple, 2012). In order to quantify the magnitude of fluvial incision in the lower reaches of the studied drainage, the upstream graded relict profiles of tributaries can be reconstructed downstream until the trunk river using the mathematic formula of an idealized equilibrium long profile (Bishop and Goldrick, 2000; Goldrick and Bishop, 2007). The magnitude of incision is then calculated by subtracting the elevation of the modern long profile from that of the projected relict profile at the junction (e.g., Antón et al., 2012; Kirby and Whipple, 2012).

To describe and quantify the river long profile shape, the profiles were extracted from $10 \mathrm{~m}$ resolution digital elevation models (DEM) generated from digital topographic maps $(1 / 25,000$ scale). For each stream, elevation, distance, and drainage area data were compiled utilizing a group of built-in ArcGIS functions. Longitudinal profiles (distance versus elevation) were then plotted. The recognition of an equilibrium relict profile in the upstream reach of the studied streams was then performed visually and analytically corroborated by constructing distance-slope (DS) plots for each stream and verifying the goodness of fit to a linear trend for that upper reach. The DS plots are derived from the power law relationship between slope and downstream distance (D, or L; Bishop and Goldrick, 2000; Goldrick and Bishop, 2007; Eq. (1)),

$S=k L^{-\lambda} \quad$ or $\quad \ln S=\gamma-\lambda \ln L$

where $S$ is the slope at a point along the stream profile, $L$ is the 


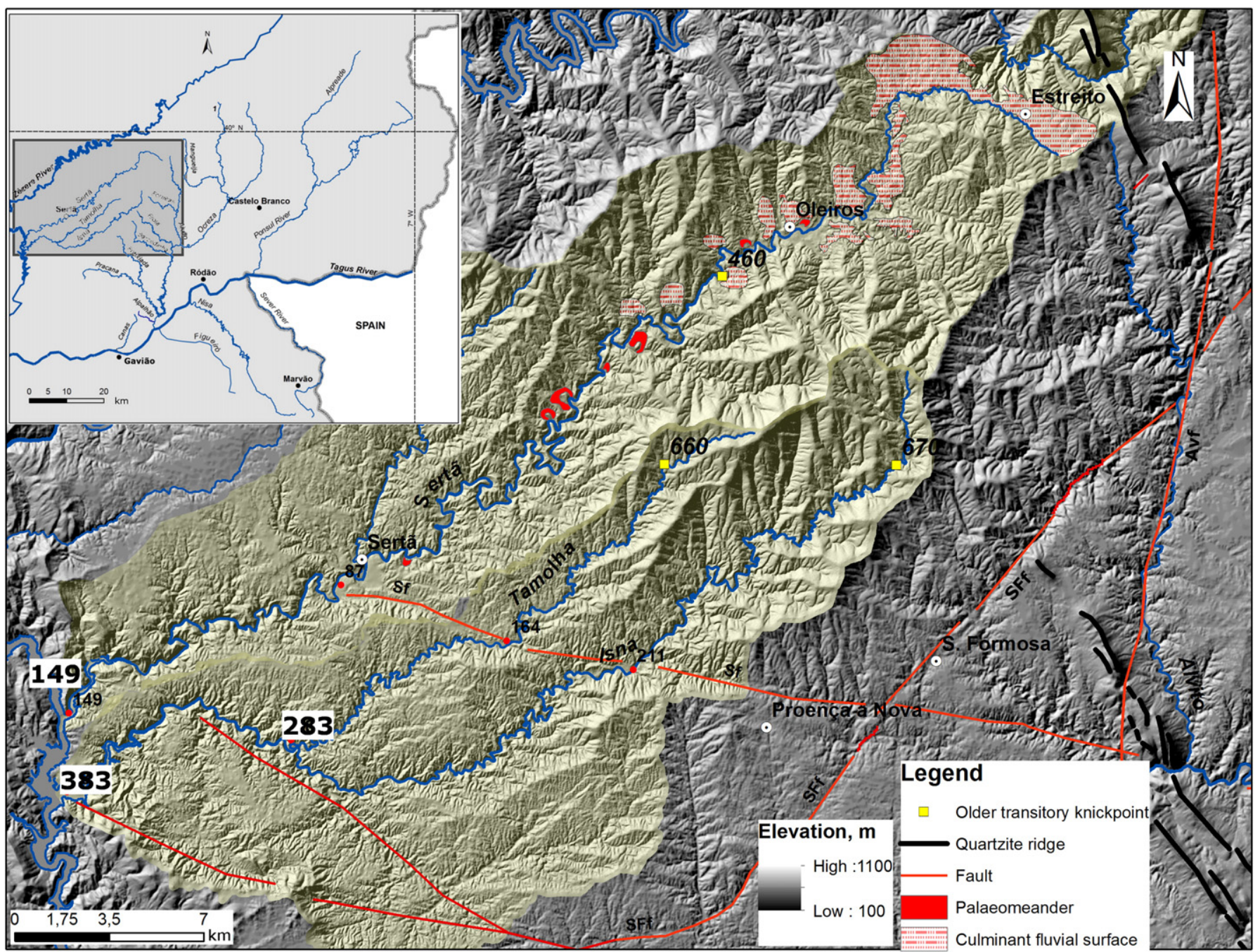

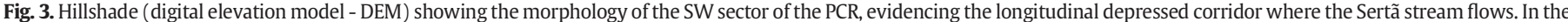

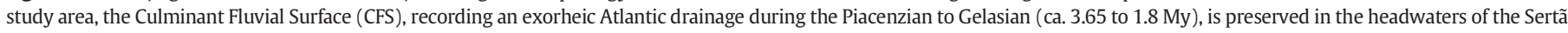

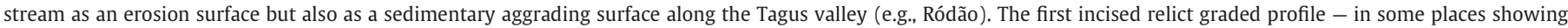

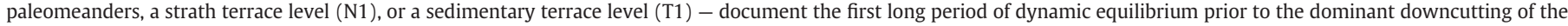

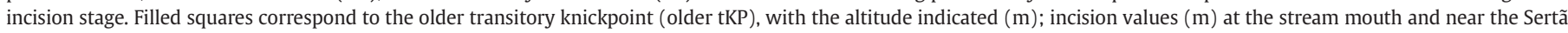
fault are also indicated. Sf - Sertã fault; SFf - Sobreira Formosa fault; AVf - Alvito fault.

downstream distance from the drainage divide to that point, $k$ and $\lambda$ are constants, and $\gamma$ is equal to the natural logarithm of $k(\ln k)$. The exponent $\lambda$ relates to the long profile concavity, while the parameter $k$ reflects the influence of lithology and other factors, including equilibrium incision rate and stream hydraulic geometry.

The slope model described by Eq. (1) can be expressed in terms of a derivative of elevation with respect to distance, such that $S=d H / d L$. From this equation, the graded long profile can be obtained by integration:

$\mathrm{H}=\int S d L$

Replacing $S$ by the value given by Eq. (1) and integrating produces the equilibrium long profile formula:

$H=H_{0}-k \frac{L^{1-\lambda}}{1-\lambda}$

where $H_{0}$ is an integration constant, and $\lambda \neq 1$. The $H_{0}$ (the value of $H$ for $L=0$ ) stands as an estimate of the theoretical elevation of the drainage divide if hydraulic processes were active right up to this point (Montgomery and Dietrich, 1988; Goldrick and Bishop, 2007).
The theoretical shape of the equilibrium relict profile thus identified in each stream was then derived by a regression analysis of the plotted longitudinal profile to a power function expressed by Eq. (1). The $k$ and $\lambda$ parameters adequate for each relict profile were then obtained and the shape of the profile was derived from Eq. (3). For each stream, $H_{0}$ was adjusted by imposing a vertical shift onto the modeled profile so that it fitted with the DEM extracted profile. The best adjustment was sought by minimizing the average of the differences in elevation between the points obtained from the DEM and the elevation of the theoretical profile points.

As stated, the streams of the study area flow through faultbounded crustal blocks affected by different uplift rates (Cabral and Ribeiro, 1993; Cabral, 1995, 2012). Some flow along the PCR, others flow from the PCR to the southern piedmont area, while others flow on the SPPS (where the Cenozoic sedimentary cover is mostly eroded). Considering this diverse setting relative to the regional neotectonic structures, we also explored the stream profiles to extract tectonic activity using the steepness index factor (Wobus et al., 2006), which is a parameter sensitive to tectonics, particularly to changes in strain rates.

The steepness index can be extracted from the power law relationship between slope and the contributing drainage area (Hack, 1973; 
Flint, 1974; Howard and Kerby, 1983), as in Eq. (4):

$S_{e}=k s A^{-\theta}$

where $S_{e}$ is the equilibrium channel gradient, $k_{s}$ and $\theta$ are parameters that describe the relative steepness and the concavity of the curve in the plot of the slope versus drainage area, respectively. The concavity index $(\theta)$ expresses the rate of stream gradient change with the drainage area and corresponds to the slope of the linear expression of that function in a log slope-log area plot, while the steepness index $\left(k_{s}\right)$ corresponds to the $y$-intercept in this plot. Eq. (4) holds only above a critical drainage area, usually interpreted as the transition from debris-flows to fluvial processes within a drainage basin (Wobus et al., 2006).

Both the concavity index $(\theta)$ and the steepness index $\left(k_{s}\right)$ are easily obtained by linear regression of the $\log$ of stream gradient $(\log S)$ versus the log of upstream drainage area $(\log A)$. However, because small variations and uncertainties of the concavity index can significantly influence the value of $k_{s}$ derived from linear regression, the regressions are usually done with an imposed reference concavity $\left(\theta_{\text {ref }}\right)$, and a normalized steepness index $\left(k_{s n}\right)$ is thus obtained. The reference concavity is usually taken as the regional mean of the observed $\theta$ values, which in undisturbed segments typically fall in a range of 0.30 to 0.60 (Whipple and Tucker, 1999; Snyder et al., 2000; Kirby and Whipple, 2001; Kirby et al., 2003; Wobus et al., 2006).

Many streams show a single slope-area scaling for their entire length; but for tectonic information to be extracted from the landscape it is preferable to analyze individual segments, as each segment may exhibit a different value of $k_{s n}$ (Wobus et al., 2006). In fact, the simplest approach is to use a single regression from headwaters to the stream mouth, but the normalized steepness index thus obtained determines a value representative of the centroid of the data bound by the upstream and downstream limits of the regression. Recognizing the segmented nature of river profiles and choosing these limits is thus an important methodological step.

In this study, the normalized steepness indices were calculated using the method of Wobus et al. (2006), described above. After examining the slope-area data of each stream, we divided the long profile into individual segments, and for each one the appropriate regression limits were chosen. The channel steepness index $\left(k_{s}\right)$ and concavity index $(\theta)$ were calculated using the power law regression of river slope against drainage area (Eq. 4). A second regression calculation was then undertaken whereby individual segments of slope-area data were fitted using a reference concavity $\left(\theta_{\text {ref }}\right)$ to determine the normalized steepness index $\left(k_{s n}\right)$ of each segment. A value of 0.45 was used as the reference concavity, taking into account the obtained regional values of concavity indices.

The different segments of the studied rivers are separated by knickpoints or knickzones marked by a distinctive change in channel gradient. These correspond mostly to slope-break knickpoints (Whipple et al., 2013), consisting of a longitudinally extensive change in channel gradient from an upper graded relict profile to a steeper, rejuvenated lower reach. These knickpoints/zones separate channel reaches with different channel steepness $\left(k_{s}\right)$ values and are readily recognized on long profiles and on slope-area plots (e.g., Wobus et al., 2006). Localized, vertical step knickpoints are also easily recognizable on the long profiles and as spikes in DS and in slope-area plots, while a broad zone of disequilibrium steepening is clearly expressed as an area of dispersed and incoherent distribution of points in DS plots (Goldrick and Bishop, 2007).

The recognition of knickpoints or knickzones in the studied streams was first performed by visual inspection of the stream profiles and then analytically corroborated in DS and $\log S-\log A$ plots, according to the above referred criteria. Several knickpoints and knickzones were thus identified and classified as either transitory (mobile) or permanent (stationary). Transitory knickpoints or knickzones develop in response to disturbances in the steady state conditions of the long profile and pinpoint the present location of an upstream propagating incision wave or of a channel steepness adjustment (Howard et al., 1994; Crosby and Whipple, 2006). Permanent knickpoints/zones are typically associated with resistant bedrock lithologies (rKP).

\section{Stream profile analysis results}

\subsection{Streams flowing along the Portuguese Central Range}

This group comprises the Sertã, Tamolha, and Isna streams, whose valleys are located within the PCR and trend longitudinally to the mountain system, flowing NE-SW (Figs. 2 and 3). The 78 km-long Sertã stream is located within a corridor, at ca. $450-500 \mathrm{~m}$ of altitude, while the Tamolha and Isna streams probably flow along a tectonically more elevated block (ca. $1100 \mathrm{~m}$ of maximum altitude).

The long profiles of these streams (Fig. 4A, B, and C) reveal an upstream relict graded profile and a downstream rejuvenated reach, separated by a knickpoint (tKP) situated at altitudes of $460 \mathrm{~m}$ (Sertã), $670 \mathrm{~m}$ (Isna), and $660 \mathrm{~m}$ (Tamolha; Older transitory knickpoint on Fig. 3). The amount of migration of the older tKP from the stream mouth to its current position(s) is a function of the drainage area (Fig. 5). Effectively, the older tKP has traveled farther along the Sertã stream (60 km). However, in the Sertã stream, the relict profile still represents around $20 \%$ of the total length, while for the other streams it only represents $<10 \%$.

The distance-slope (DS) plots for the three rivers (Fig. 4A, B, C inset plots) indicate that the relict profiles (lozenges) are close to graded, while the more disordered points of the rejuvenated profiles (crosses) indicate ungraded profiles. Other transitory knickpoints, located between the older tKP and the Sertã fault, were recognized on the rejuvenated profiles.

The incision value, calculated from the difference in elevation between the downstream projection of the relict graded profile and the modern river bed at the stream mouth (Tables 1, 2, and 3), is significantly less in the Sertã stream (ca. $150 \mathrm{~m}$ ) compared with the Tamolha (ca. $280 \mathrm{~m}$ ) and Isna (ca. $380 \mathrm{~m}$ ) streams.

To evaluate the influence of the Sertã fault on the stream profiles, we used the normalized steepness index $\left(k_{s n}\right)$ extracted from slope/area data (Table 4). The $k_{s n}$ of the relict profile (reach upstream of the older tKP) and of the rejuvenated reaches were calculated separately. In the rejuvenated profile, the segments located upstream and downstream of the fault were also considered separately to compare the $k_{s n}$ values for uplifted and subsided tectonic blocks.

The $k_{s n}$ values of the relict profiles and of the rejuvenated profiles upstream the Sertã fault increase from the Sertã stream (flowing in a less uplifted block) to the Isna and the Tamolha streams, which flow in a relatively more uplifted block (Fig. 3 ). However, the $k_{s n}$ values of the rejuvenated profiles downstream of the Sertã fault do not show a uniform variability tendency between the three streams: for the Tamolha and Isna streams, the $k_{s n}$ values diminish in the downstream side of the Sertã fault, while for the Sertã stream it is the opposite. This stream probably does not cross the Sertã fault, which ends near the town of Sertã, SE of the stream. So, for the Sertã stream, the increase in $k_{s n}$ value of the reach downstream of Sertã should be related to an incision wave rejuvenation triggered from the Zêzere River. For the Isna and Tamolha streams, routed by an antecedence process through the southeastern uplifted block of the Sertã fault, the incision wave has been counterbalanced by the uplift forming a reduced channel gradient $\left(k_{s n}=31\right)$. This reduction seems consistent with some vertical component in this right lateral slip fault, whose strike-slip component is well expressed by a significant (ca. $2 \mathrm{~km}$ ) dextral stream channel offset.

\subsection{Streams flowing from the Portuguese Central Range to the South Portu- gal Planation Surface}

The streams of this group (Tripeiro, Mangueija, Alvito, Fórneas, Froia, Sarzedinhas, and Freixiada) are tributaries of the Ocreza River that cross 

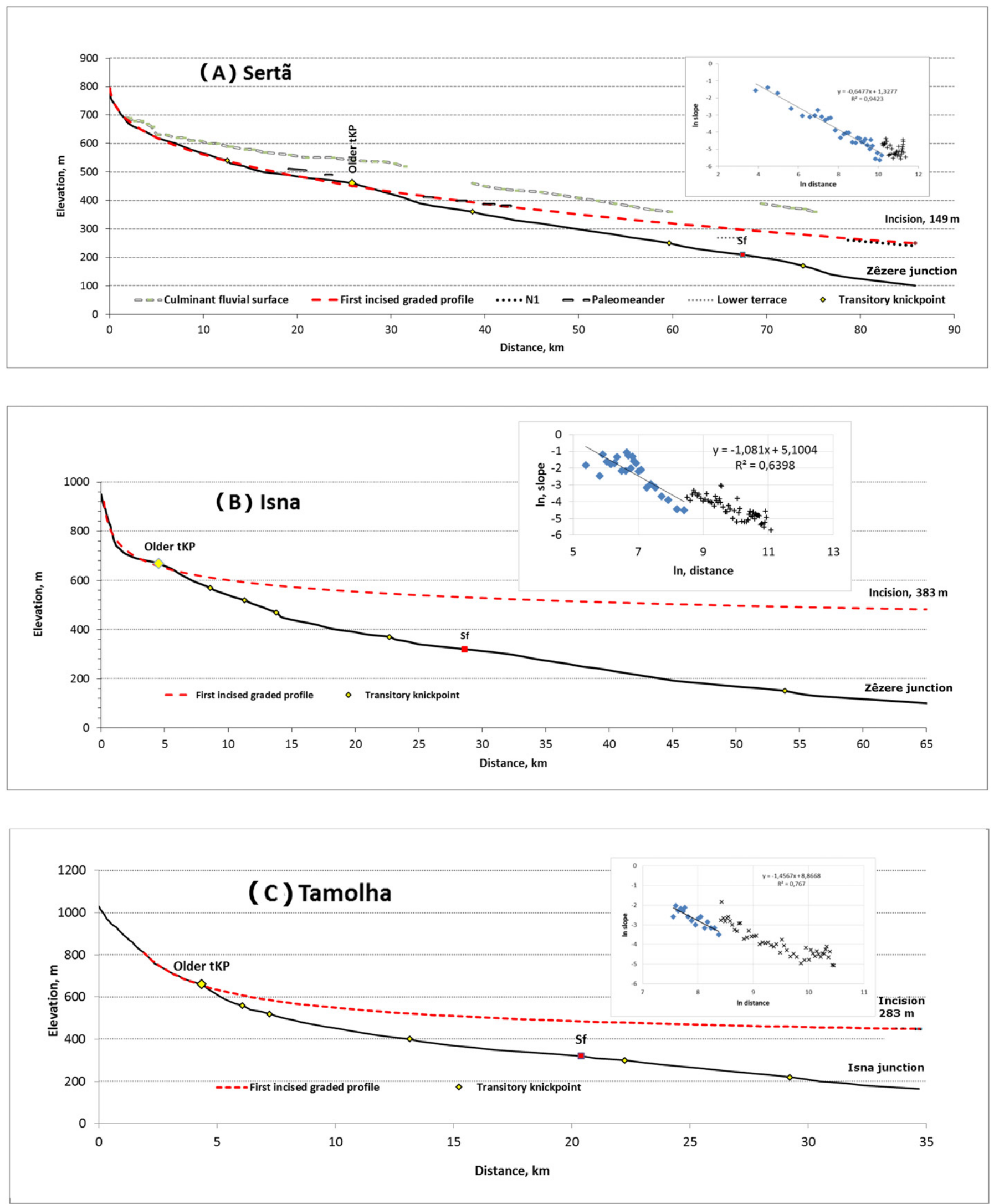

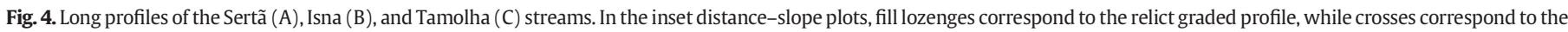
rejuvenated profile located downstream of the older transitory knickpoint (tKP). The red squares indicate the position of the Sertã fault. 


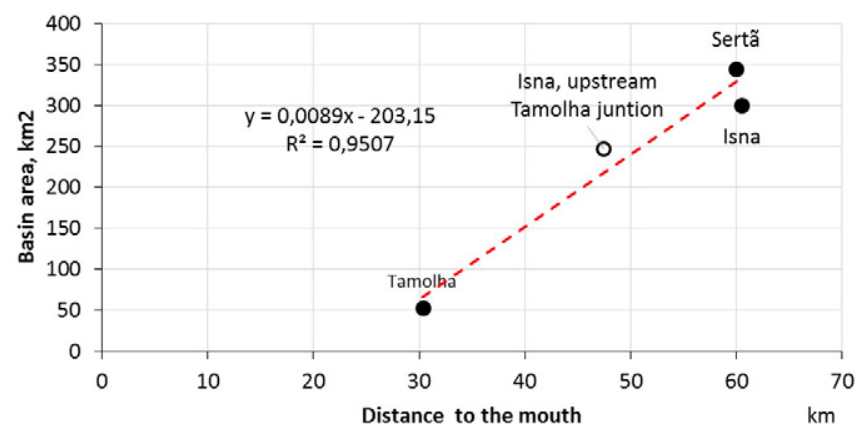

Fig. 5. Distance traveled by older transitory knickpoint from the mouth versus the drainage area for the Sertã, Isna, and Tamolha streams.

the Sobreira Formosa fault (SFf) along the SE side of the PCR (Figs. 2 and 6). In this sector the tributary drainage flows on Neoproterozoic to Cambrian phyllites, slates, and metagreywackes, except for the Ocreza River which crosses an area of granite in its upstream part and metasedimentary rocks in the downstream rejuvenated reach. The Ocreza River will be included in the fluvial system that runs on the SPPS because it flows mostly on the planation surface.

For the streams of this group, the reach upstream of the SFf is characterized by a smooth concave-up shape located headward of an older tKP, while downstream occur several scattered transitory vertical step-knickpoints (Figs. 7 and 8). This upper section is generally very short, $<10 \%$ of the total channel length and, although poorly preserved, it has been considered as a remnant of an upper graded reach. Thus, after subtracting the hillslope/colluvial reach in the upstream limit of the streams, the contributing area upstream of the older tKP approaches the critical area $\left(A_{\text {crit }}\right)$ below which the knickpoint cannot propagate farther upstream. The critical area falls in a range of $0.1-5 \mathrm{~km}^{2}$ (Montgomery and Foufoula-Georgiou, 1993; Wobus et al., 2006; Kirby and Whipple, 2012).

The area upstream of the older tKP is $8.8 \mathrm{~km}^{2}$ for the Alvito stream and is even smaller for several of the other streams. The migrating incision waves are therefore close to the upper limit of their upstream propagation, and the relict profile is almost nonexistent. Owing to the short length of the relict profile, its reconstruction down to the stream mouth is problematic, and the amount of the incision is undetermined in several cases or uncertain in the others (Figs. 7 and 8; Table 2).

For these streams, the $k_{s n}$ value of the remnant relict graded reach compared to the $k_{s n}$ values of the downstream rejuvenated reaches are similar for the Alvito stream, slightly lower for the Sarzedinha and Fórneas streams, and higher for the other streams of this group (Fróia and Mangueja). The Fróia (Fig. 7B) and the Tripeiro (Fig. 9B) streams flow in a less resistent metamorphic basement, but the Ocreza River flows largely in the hard granite basement (Figs. 2 and 6).

For all of the streams of this group, the $k_{s n}$ value systematically increases in reaches upstream of the SFf, compared to those on the downstream side of the fault, which flow on the mountain piedmont. This spatial variability of $k_{s n}$ values may indicate some continued uplift of the PCR, explaining the set of transitory knickpoints in the reaches located between the SFf and the older tKP. In fact, the long profile

Table 1

Topographic characteristics of streams flowing in the Portuguese Central Range.

\begin{tabular}{lllllll}
\hline Stream & $H_{0}$ & $H_{i}$ & $H_{f}$ & $k$ & $\lambda$ & Incision \\
\hline Sertã & 836 & 780 & 460 & 3.77 & 0.64 & $149 \pm 5$ \\
Isna & -132 & 900 & 670 & 166.9 & 1.10 & $383 \pm 12$ \\
Tamolha & 317 & 810 & 660 & 7093 & 1.45 & $283 \pm 2$ \\
\hline
\end{tabular}

$\mathrm{H}_{\mathrm{O}}$ is an estimate of the theoretical elevation of the divide, if hydraulic processes were active right to the drainage head, corresponding to the necessary adjustment (up or down) in order to obtain the best fit of the idealized curve to the real profile; $H_{i}$ and $H_{f}$ are the altitudes in the edge of the analyzed stream reach, $k$ and $\lambda$ are constants reflecting the steepness and curve concavity; incision values are in meters (see Goldrick and Bishop, 2007).
Table 2

Topographic characteristics of streams flowing from the Portuguese Central Range to the South Portugal Planation Surface.

\begin{tabular}{lllllll}
\hline Stream & $H_{0}$ & $H_{i}$ & $H_{f}$ & $k$ & $\lambda$ & Incision at junction \\
\hline Alvito & 1016 & 700 & 420 & 19.30 & 0.771 & undetermined \\
Fórneas & 235 & 700 & 440 & 3463 & 1.448 & $175 \pm 11$ \\
Fróia & 2143 & 850 & 540 & 77.59 & 0.886 & undetermined \\
Sarzedinha & 1268 & 720 & 400 & 31.56 & 0.799 & $96 \pm 5$ \\
Mangueja & 450 & 710 & 550 & 17,161 & 1.778 & $261 \pm 16$ \\
Tripeiro & 20 & 640 & 260 & 1837 & 1.314 & $34 \pm 28$ \\
\hline
\end{tabular}

$H_{0}$ is an estimate of the theoretical elevation of the divide if hydraulic processes were active right to the drainage head; $H_{i}$ and $H_{f}$ are the altitudes in the edge of the analyzed stream reach, $k$ and $\lambda$ are constants reflecting the steepness and curve concavity; incision values are in meters.

morphology of the reaches located upstream of the SFf suggests an upstream propagating adjustment with a permanent increase of channel steepness, inherent to an increasing rock uplift rate of the PCR relatively to the piedmont area and adjacent SPPS. The extensive changes in channel gradient of segments between the older tKP and the SFf suggest a slope-break knickpoint morphology (Kirby and Whipple, 2012; Whipple et al., 2013), separating channel reaches with different channel steepness related to differential uplift between the PCR and the piedmont area/adjacent SPPS. In the study area this is most probably accommodated by tectonic activity of the SFf.

\subsection{South Portugal Planation Surface streams}

The streams of this group flow on basement rocks of the SPPS at an altitude of 300-400 m (Fig. 2). Three main tributaries of the Tagus River (the Ponsul, Ocreza, and Sever rivers) were analyzed, together with other lower order tributaries. The Ponsul River crosses the Ponsul fault (Pf), flowing in its upstream reach on granites and metasediments of the northern uplifted block of the fault (at 400-450 m) and on the Cenozoic deposits at Ródão - Idanha a Nova (at ca. $200 \mathrm{~m}$ ) in its lower reach downstream of the fault. The Ocreza River flows mostly on the Precambrian to Palaeozoic basement of the crustal block located between the SFf, at the north, and the Pf, at the south, crossing granites in the upstream part and metasediments in the lower reach (Figs. 2 and 6). The Sever River flows mostly on Precambrian to Palaeozoic metasediments but also on granite and quartzites in the upstream part (Fig. 2).

As for the previously described streams, those that flow on the SPPS display an upstream relict graded profile and a rejuvenated lower reach, separated by a pronounced slope-break knickpoint (older tKP). For the Ocreza River (Figs. 6 and 9A), the relict profile corresponds to the reach between the point situated at an altitude of $650 \mathrm{~m}$ (ca. $4 \mathrm{~km}$ from the divide), above which the DS plot lacks linearity, and the point situated at $380 \mathrm{~m}$, ca. $16 \mathrm{~km}$ from the divide. Downstream, in the rejuvenated profile, the river crosses a resistant quartzite ridge at Portas do Almourão, where it forms a deeply incised gorge (Figs. 2 and $6)$.

Table 3

Topographic characteristics of streams flowing in the South Portugal Planation Surface (the parameters on the first row are the same as those of the Tables 1 and 2).

\begin{tabular}{lllllll}
\hline Stream & $H_{0}$ & $H_{i}$ & $H_{f}$ & $k$ & $\lambda$ & Incision \\
\hline Ocreza & 240 & 630 & 300 & $3,612,822$ & 2.057 & $214 \pm 23$ \\
Sever & 699 & 600 & 490 & 1.512 & 0.563 & $199 \pm 2$ \\
Alpreade/Ponsul & 5240 & 600 & 330 & 60.91 & 0.985 & $153 \pm 12$ \\
Nisa & 89 & 600 & 390 & 693 & 1.244 & $209 \pm 8$ \\
Figueiró & 378 & 340 & 310 & 1.376 & 0.685 & $221 \pm 3$ \\
Freixiada & 761 & 560 & 410 & 15.47 & 0.855 & $137 \pm 11$ \\
Pracana & 806 & 430 & 210 & 21.52 & 0.918 & $116 \pm 3$ \\
Canas & 844 & 300 & 220 & 24.55 & 0.933 & $110 \pm 3$ \\
Alpalhão & 362 & 330 & 290 & 1.44 & 0.580 & $159 \pm 3$ \\
\hline
\end{tabular}


Table 4

Normalized steepness index $\left(k_{s n}\right)$ of the studied streams.

\begin{tabular}{|c|c|c|c|c|c|}
\hline Stream & $A_{\text {min. }}\left(m^{2}\right)$ & $A_{\max .}\left(m^{2}\right)$ & $\theta$ & $k_{s n}(\Theta=0.45)$ & Reach \\
\hline \multirow[t]{3}{*}{ Sertã } & $1.91 \mathrm{E}+04$ & $1.03 \mathrm{E}+08$ & 0.46 & 26 & First graded incised profile \\
\hline & $1.03 \mathrm{E}+08$ & $2.91 \mathrm{E}+08$ & 0.82 & 33 & Rejuvenated profile upstream fault, at $450-210 \mathrm{~m}$ a.s.l. \\
\hline & $2.91 \mathrm{E}+08$ & $3.45 \mathrm{E}+08$ & -0.87 convex reach & 46 & Rejuvenated profile downstream fault, at $210-100 \mathrm{~m}$ a.s.l. \\
\hline \multirow[t]{3}{*}{ Isna } & $1.82 \mathrm{E}+04$ & $9.86 \mathrm{E}+06$ & 0.48 & 31 & First graded incised profile \\
\hline & $9.86 \mathrm{E}+06$ & $7.58 \mathrm{E}+07$ & 0.54 & 40 & Rejuvenated profile upstream fault \\
\hline & $7.58 \mathrm{E}+07$ & $3.05 \mathrm{E}+08$ & 0.27 & 31 & Rejuvenated profile downstream fault \\
\hline \multirow[t]{3}{*}{ Tamolha } & $9.64 \mathrm{E}+05$ & $3.87 \mathrm{E}+06$ & 0.77 & 50 & First graded incised profile \\
\hline & $3.87 \mathrm{E}+06$ & $3.45 \mathrm{E}+07$ & 1.02 & 55 & Rejuvenated profile upstream fault \\
\hline & $3.45 \mathrm{E}+07$ & $5.25 \mathrm{E}+07$ & 0.46 & 31 & Rejuvenated profile downstream fault \\
\hline \multirow[t]{3}{*}{ Alvito } & $5.66 \mathrm{E}+05$ & $8.86 \mathrm{E}+06$ & 0.60 & 42 & First graded incised profile \\
\hline & $8.86 \mathrm{E}+06$ & $6.21 \mathrm{E}+07$ & 0.61 & 43 & Rejuvenated profile upstream fault \\
\hline & $6.21 \mathrm{E}+07$ & $1.87 \mathrm{E}+08$ & 0.04 convex reach & 24 & Rejuvenated profile downstream fault \\
\hline \multirow[t]{3}{*}{ Fórneas } & $5.55 \mathrm{E}+02$ & $6.38 \mathrm{E}+06$ & 0.43 & 50 & First graded incised profile \\
\hline & $6.38 \mathrm{E}+06$ & $2.61 \mathrm{E}+07$ & 0.19 & 59 & Rejuvenated profile upstream fault \\
\hline & $2.61 \mathrm{E}+07$ & $8.06 \mathrm{E}+07$ & 0.60 & 24 & Rejuvenated profile downstream fault \\
\hline \multirow[t]{3}{*}{ Fróia } & $5.08 \mathrm{E}+04$ & $1.12 \mathrm{E}+06$ & 0.57 & 67 & First graded incised profile \\
\hline & $1.12 \mathrm{E}+06$ & $1.25 \mathrm{E}+07$ & 0.65 & 52 & Rejuvenated profile upstream fault \\
\hline & $1.25 \mathrm{E}+07$ & $5.65 \mathrm{E}+07$ & 0.60 & 35 & Rejuvenated profile downstream fault \\
\hline \multirow[t]{3}{*}{ Sarzedinha } & $1.95 \mathrm{E}+04$ & $3.26 \mathrm{E}+06$ & 0.40 & 35 & First graded incised profile \\
\hline & $3.26 \mathrm{E}+06$ & $2.31 \mathrm{E}+07$ & 0.82 & 49 & Rejuvenated profile upstream fault \\
\hline & $2.31 \mathrm{E}+07$ & $6.01 \mathrm{E}+07$ & 0.32 & 27 & Rejuvenated profile downstream fault \\
\hline \multirow[t]{3}{*}{ Mangueja } & $6.34 \mathrm{E}+03$ & $2.54 \mathrm{E}+06$ & 0.43 & 41 & First graded incised profile \\
\hline & $2.54 \mathrm{E}+06$ & $5.03 \mathrm{E}+07$ & 0.58 & 37 & Rejuvenated profile upstream fault \\
\hline & $5.03 \mathrm{E}+07$ & $1.44 \mathrm{E}+08$ & 0.35 & 21 & Rejuvenated profile downstream fault \\
\hline \multirow[t]{4}{*}{ Tripeiro } & $3.83 \mathrm{E}+03$ & $6.79 \mathrm{E}+07$ & 0.56 & 41 & First graded incised profile \\
\hline & $1.39 \mathrm{E}+05$ & $6.79 \mathrm{E}+07$ & 0.74 & 102 & First graded incised profile downstream $730 \mathrm{~m}$ a.s.l. \\
\hline & $6.79 \mathrm{E}+07$ & $3.49 \mathrm{E}+08$ & 0.45 & 24 & First graded incised profile downstream fault \\
\hline & $1.88 \mathrm{E}+04$ & $1.81 \mathrm{E}+07$ & 0.49 & 44 & First graded incised profile upstream fault \\
\hline \multirow[t]{6}{*}{ Ocreza } & $4.00 \mathrm{E}+05$ & $1.81 \mathrm{E}+07$ & 0.64 & 138 & First graded incised profile upstream fault, reach at $1000-390 \mathrm{~m}$ a.s.l. \\
\hline & $1.81 \mathrm{E}+07$ & $1.75 \mathrm{E}+08$ & 0.66 & 33 & First graded incised profile downstream fault \\
\hline & $1.75 \mathrm{E}+08$ & $1.99 \mathrm{E}+08$ & -4.7 convex reach & 72 & Rejuvenated profile on granite \\
\hline & $1.99 \mathrm{E}+08$ & $1.44 \mathrm{E}+09$ & 0.54 & 46 & Rejuvenated profile on schist \\
\hline & $2.00 \mathrm{E}+08$ & $7.90 \mathrm{E}+08$ & 0.84 & 35 & Rejuvenated profile on schist upstream Almourão gorge \\
\hline & $9.79 \mathrm{E}+08$ & $1.44 \mathrm{E}+09$ & -1.8 convex reach & 46 & Rejuvenated profile on schist downstream Almourão gorge \\
\hline \multirow[t]{3}{*}{ Nisa } & $4.80 \mathrm{E}+05$ & $4.43 \mathrm{E}+07$ & 0.84 & 33 & First graded incised profile \\
\hline & $4.43 \mathrm{E}+07$ & $1.67 \mathrm{E}+08$ & 0.74 & 33 & Rejuvenated profile upstream rKP \\
\hline & $1.67 \mathrm{E}+08$ & $2.65 \mathrm{E}+08$ & -3.3 convex reach & 81 & Rejuvenated profile downstream rKP \\
\hline \multirow[t]{3}{*}{ Ponsul } & $1.89 \mathrm{E}+04$ & $1.05 \mathrm{E}+07$ & 0.33 & 15 & First graded incised profile \\
\hline & $1.05 \mathrm{E}+07$ & $1.94 \mathrm{E}+08$ & 0.57 & 55 & Rejuvenated profile upstream fault \\
\hline & $2.59 \mathrm{E}+08$ & $1.33 \mathrm{E}+09$ & 0.56 & 25 & Rejuvenated profile downstream fault \\
\hline \multirow[t]{2}{*}{ Alpreade } & $1.37 \mathrm{E}+04$ & $9.30 \mathrm{E}+07$ & 0.50 & 30 & First graded incised profile \\
\hline & $1.04 \mathrm{E}+08$ & $5.56 \mathrm{E}+08$ & 0.0 straight reach & 48 & Rejuvenated profile \\
\hline \multirow[t]{2}{*}{ Pracana } & $5.16 \mathrm{E}+03$ & $7.97 \mathrm{E}+07$ & 0.50 & 20 & First graded incised profile \\
\hline & $8.90 \mathrm{E}+07$ & $1.99 \mathrm{E}+08$ & -0.55 convex reach & 36 & Rejuvenated profile \\
\hline Sever & $\mathrm{nc}$ & nc & - & - & - \\
\hline \multirow{4}{*}{$\begin{array}{l}\text { Figueiro } \\
\text { Canas }\end{array}$} & nc & $\mathrm{nc}$ & - & - & - \\
\hline & $1.32 \mathrm{E}+05$ & $3.18 \mathrm{E}+06$ & 0.60 & 19 & First graded incised profile \\
\hline & $4.43 \mathrm{E}+06$ & $1.77 \mathrm{E}+07$ & 0.90 & 21 & Rejuvenated profile upstream rKp \\
\hline & $4.43 \mathrm{E}+06$ & $4.36 \mathrm{E}+07$ & -0.15 convex reach & 39 & All rejuvenated profile \\
\hline \multirow[t]{3}{*}{ Alpalhão } & $3.47 \mathrm{E}+03$ & $8.39 \mathrm{E}+05$ & 0.36 & 8 & First graded incised profile \\
\hline & $1.24 \mathrm{E}+06$ & $9.36 \mathrm{E}+06$ & 0.76 & 25 & Rejuvenated profile upstream $160 \mathrm{~m}$ \\
\hline & $9.36 \mathrm{E}+06$ & $9.36 \mathrm{E}+06$ & -4.7 convex reach & 64 & Rejuvenated profile downstream $160 \mathrm{~m}$ a.s.l. \\
\hline
\end{tabular}

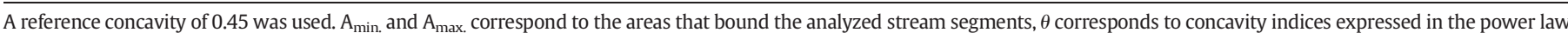
function between slope and the contributing drainage area (Eq. (4)).

The best fit projection of the relict profile was difficult to obtain for the Ocreza River owing to the fact that it presents a sharp vertical step knickpoint associated to the SFf, ca. $9 \mathrm{~km}$ from the divide (Fig. 9A). This vertical step knickpoint has a convex shape with an abrupt slope break downstream ( 0.05 gradient between elevations of 410 and $390 \mathrm{~m}$ ). This shape contrasts with the concave up profile of the streams flowing through metasedimentary rocks of the SE slope of the PCR, upstream of the SFf (Figs. 7 and 8). This seems to indicate that in the granites (where the former knickpoint is located) the rates of erosion are intensified at the face and base of the knickpoint (parallel slope retreat), while in schist the concave up shape suggests higher erosion rates near the knickpoint lip. A second oversteepened reach, located at ca. $28 \mathrm{~km}$ from the divide (Fig. 9A), corresponds to an old transitory knickpoint that marks the upstream limit of the regional incision wave propagation. Another fixed knickpoint occurs at $63 \mathrm{~km}$ from the divide and is related to the crossing of the resistant quartzite ridge at Portas do Almourão gorge (permanent knickpoint). In spite of the difficulty in obtaining the best fit projection of the relict profile, incision quantification indicates $129 \mathrm{~m}$ at the Almourão gorge and $214 \mathrm{~m}$ at the confluence with the Tagus River.

The SFf segmented the relict profile of the Ocreza River in two reaches with different steepness. The $k_{s n}$ index of the relict profile upstream of the fault $\left(k_{s n}=138\right.$, between 650 and $390 \mathrm{~m}$ ) is significantly higher than the $k_{s n}$ index of the relict profile downstream of the SFf $\left(k_{s n}=33\right)$. In the rejuvenated profile, the channel steepness increases in the granite basement $\left(k_{s n}=72\right)$ compared to the channel steepness of the river in slates and metagreywackes $\left(k_{s n}=46\right)$. The older tKP is on top of the rejuvenated profile, and the related downstream knickzone is 


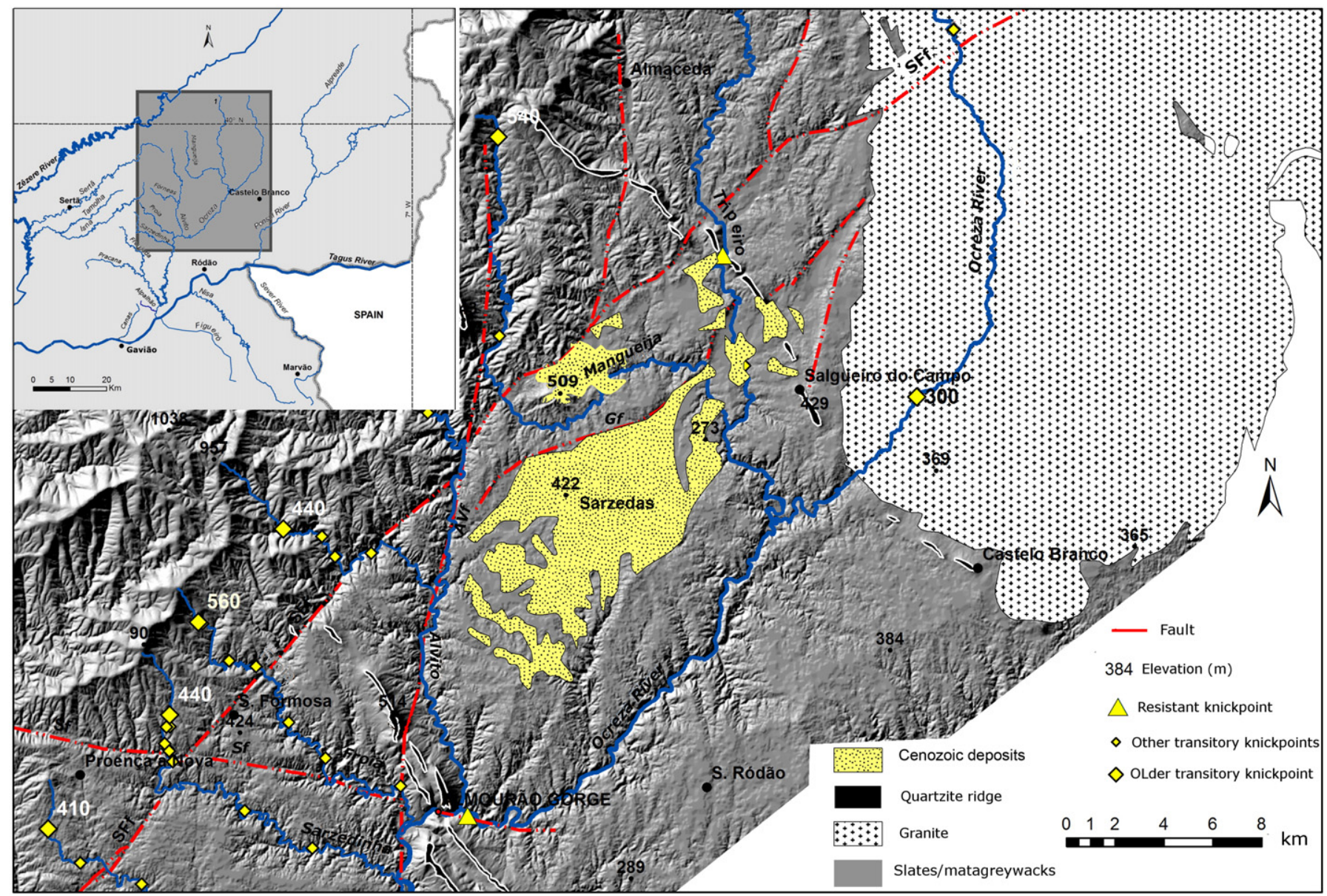

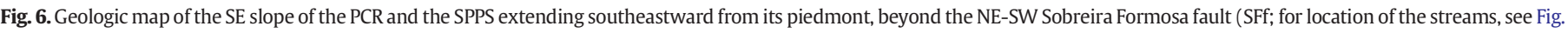

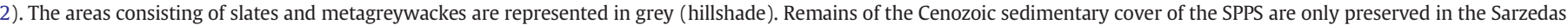

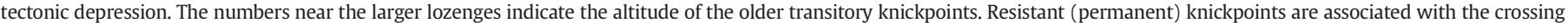

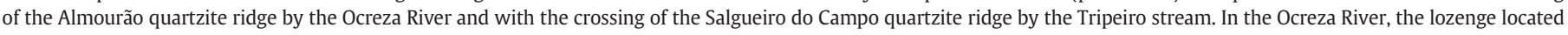
immediately upstream of the SFf is interpreted as a transitory knickpoint with tectonic origin.

located near the contact between slates/metagreywackes and granite. This knickzone is, in some way, anchored to the lithological contact, considering the extension of the granite batholith. Upstream of the Almourão gorge at the quartzite ridge, the channel steepness is slightly lower $\left(k_{s n}=35\right)$ than the steepness of the reach downstream of the gorge $\left(k_{s n}=46\right.$; Table 4$)$, suggesting that erosion waves migrating from the river mouth are pinned to the quartzite ridge, generating a fixed vertical step knickpoint.

The Ponsul River reveals several knickpoints, but the older tKP was difficult to identify because of the construction of a dam. In these circumstances, we used a tributary of the Ponsul River (the Alpreade stream; Figs. 2 and 10A) to calculate the fluvial incision. The Ponsul River crosses the Ponsul fault (Pf; Fig. 2), upstream of which occurs a knickzone with vertical step knickpoints at the contact between the slates/metagreywackes and granite. The downstream limit of the knickzone coincides with the transition from the soft Cenozoic deposits in the downthrown side of the Pf to the harder basement rocks in the upthrown side of the Pf. A vertical incision of ca. $150 \mathrm{~m}$ was estimated for the Alpreade/Ponsul system at the confluence with the Tagus River (Table 3).

The Figueiró, the Nisa, and the Sever streams flow toward the NW because they are located in a block tilted to the NW (the downthrown side of the Pf; Fig. 2), and this justifies the similarities in long profile shape and high incision quantification (ca. 200-220 m).

In the Nisa stream (Fig. 10B), the transitory knickpoint in the upstream limit of the rejuvenation incision wave is at $10 \mathrm{~km}$ from the divide (older tKP). A fixed vertical step knickpoint (rKP) also occurs at $32 \mathrm{~km}$ from the divide, coinciding with a contact between slates/ metagreywackes and granite. The projection of the relict profile indicates ca. $210 \mathrm{~m}$ of vertical incision at the confluence with the Tagus River. A similar value of incision (ca. $220 \mathrm{~m}$ ) was obtained for the Figueiró stream, located slightly to the west (Fig. 11B).

In the Sever River (Fig. 10C), the older tKP is pinned to the resistant Ordovician quartzites, situated at $12 \mathrm{~km}$ from the divide. The projection of the relict graded profile gives ca. $200 \mathrm{~m}$ of vertical incision at the confluence with the Tagus River, a value similar to the height of the T1 terrace $(\mathrm{ca} .+190 \mathrm{~m}$ ) above the Tagus River bed at this location (Cunha et al., 2005, 2016).

The Pracana and Canas streams are located in similar morphotectonic settings (Fig. 2). The projection of the relict older graded profile of the Pracana stream (dashed line), downstream of the old tKP, coincides with a higher level of paleomeanders; a lower paleomeander (at $150 \mathrm{~m}$ altitude) coincides with a more incised, graded profile reach separated from the downstream reach by a tKP (Fig. 11A). The Canas stream, in an adjacent location, also shows an older tKP and a younger tKP and a similar incision (ca. $110 \mathrm{~m}$; Fig. 11C).

A set of bedrock paleomeanders occur in the Ocreza, Pracana, and Freixiada (at the Pracana junction) valleys (Fig. 12). As the long profiles of the Freixiada and Pracana streams show (Figs. 8B and 11A), the projection of these paleomeanders fit with a graded profile that is lower and therefore younger than the relict graded profile preserved upstream of the older tKP. The occurrence of distinct graded reaches in 

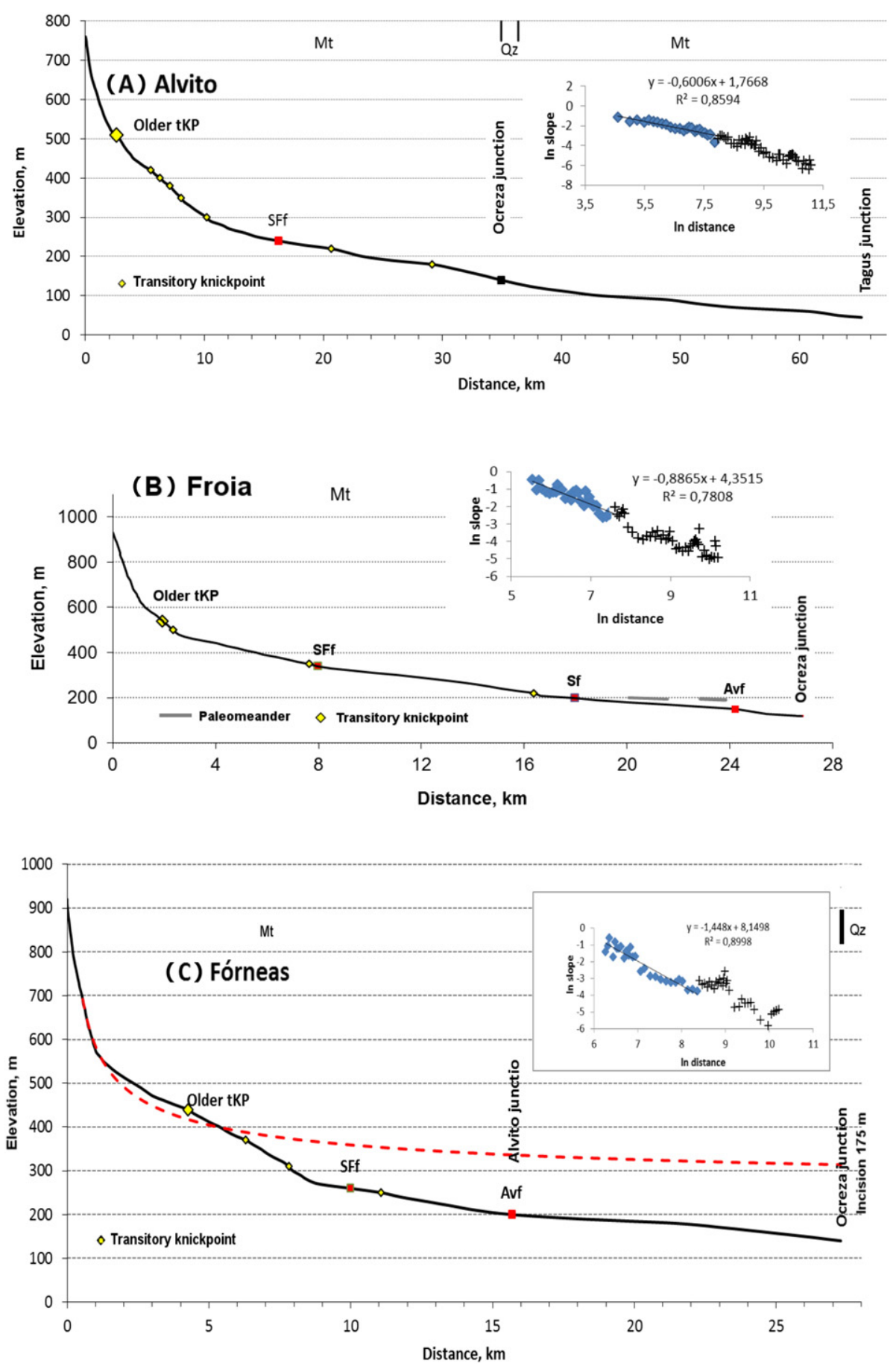

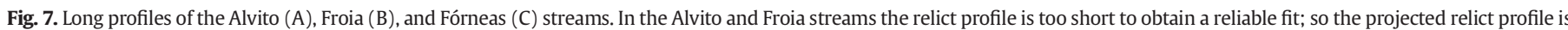

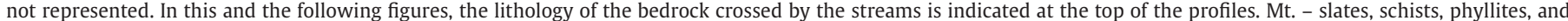

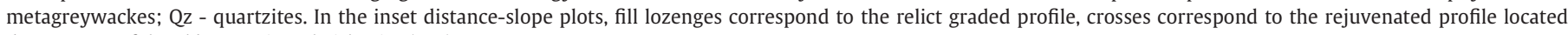
downstream of the older transitory knickpoint (tKP).

these streams points to successive phases of dynamic equilibrium and valley enlargement during the long-term process of river incision.

With the exception of the Ocreza River, which has headwaters in mountainous regions, the other streams flowing in the SPPS have relict profiles with lower steepness $\left(k_{s n}<35\right)$ than their downstream rejuvenated profiles (Table 4). This spatial variability in channel steepness is associated with an enhancement of erosion rate in the downstream areas of the dissected landscape. It suggests a model where the drainage is responding to external forcing expressed by changes in relative base level, crustal uplift rate, and climate (Whipple et al., 2013).

\section{Discussion}

Despite the quite different morphostructural contexts in which the three groups of streams flow, a common pattern is discernible for the intramountainous streams and for those flowing on the SPPS. Almost all of the streams record a relict graded profile in their upstream sector and a rejuvenated reach in the downstream sector, which are separated by a spatially well-constrained break in slope with a knickpoint on the top (older tKP). In some cases, the length of the relict profile is very short (e.g., Tamolha and Isna streams), but even in these cases it was 

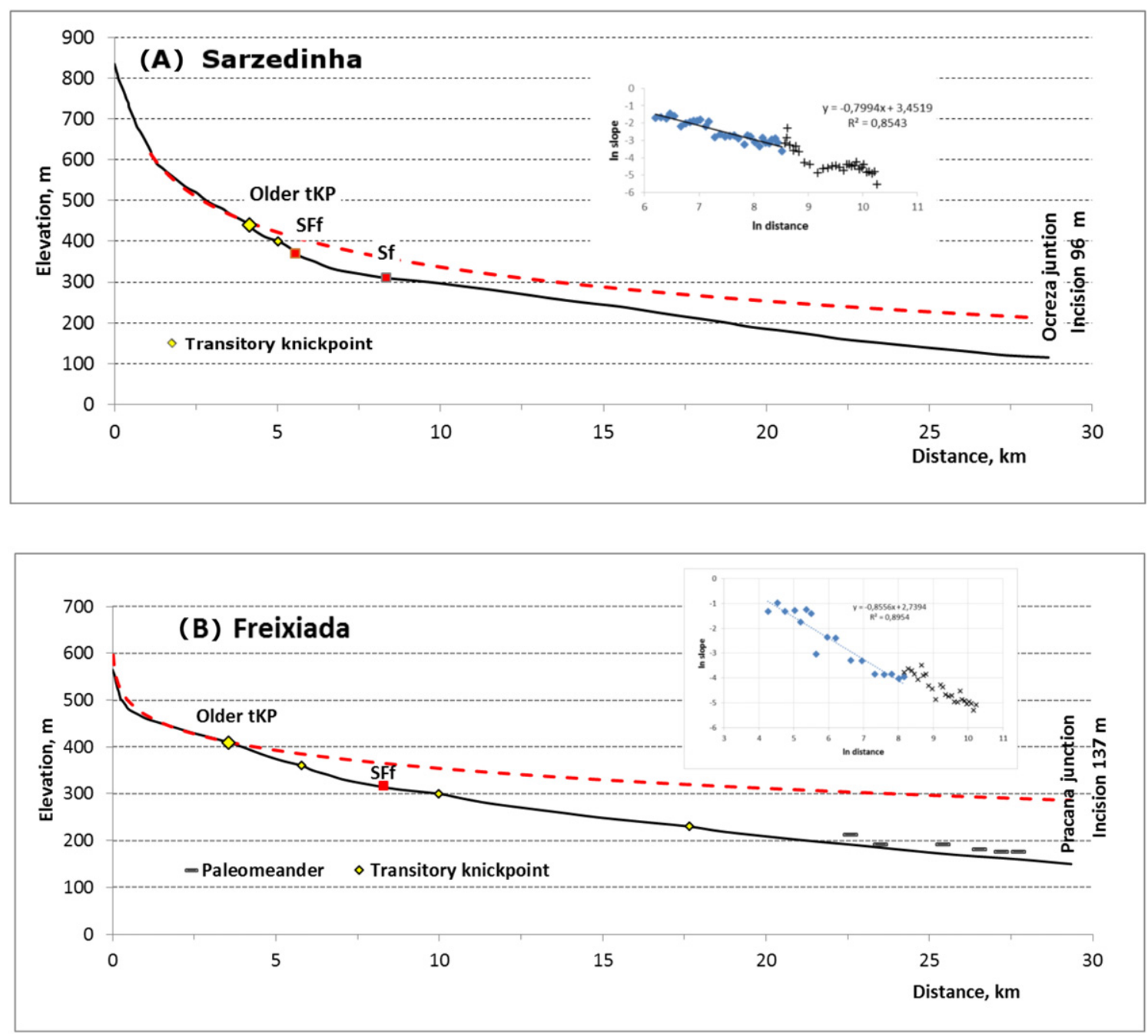

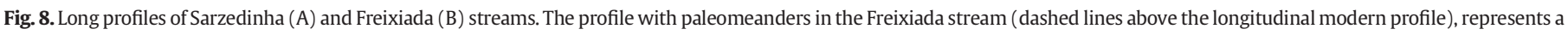

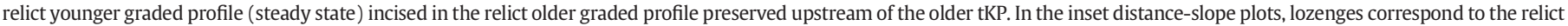
graded profile, crosses correspond to the rejuvenated profile located downstream of the older transitory knickpoint (tKP).

possible to calculate a best fit curve to the equilibrium profile and to estimate the maximum incision value at the stream mouth. In turn, the streams that flow from the PCR to the adjacent SPPS reveal that the rejuvenation incision wave migrated upstream in several streams until the critical threshold drainage area, almost completely eroding the relict profile.

For the streams that still have a relict profile, this reach has a smooth concave up form corresponding to a quasi-equilibrium profile, verified by the straight line in the inset DS plots, or in the $\log \mathrm{S}-\log \mathrm{A}$ plots. The downstream rejuvenated profiles display disordered points in the DS plots (ungraded reaches). Some segments of the rejuvenated profiles may have achieved an almost graded state upstream of knickpoints fixed in place by a resistant substrate (e.g., Ocreza River, upstream the Almourão quartzite ridge). However, while the graded reach profiles upstream of the lithologically resistant knickpoints have local significance, the relict graded profiles have a wider regional significance as they constitute a feature common to several streams in different regional contexts.

Regionally, the occurrence of the relict graded and rejuvenated profiles in the studied streams evidence a change in system conditions that had previously sustained the steady state of the relict graded profiles (Whipple et al., 2013). From that change resulted a modification in stream erosion rate that produced a downstream long profile with steeper gradient and lower concavity, especially in the final segments that become convex in many streams. The two contrasting reaches (relict graded/rejuvenated adjusting) of a given stream are evidence of the response of the fluvial system to sustained crustal uplift superimposed onto longer term conditions of lower sea level, though also influenced by climate. While the upper reaches continued to erode at the previous steady-state erosion rate and thus maintained their original form, the rejuvenated reach is adjusting to the new base-level conditions.

The concavity index values of the relict profiles range between 0.33 and 0.84 (mean 0.53). In contrast, a considerable number of rejuvenated reaches have negative concavity indices, i.e., they are poorly described by the power law relationship between local channel gradient and the upstream drainage area. The range of concavity indices of the studied relict profiles is slightly higher than the range of the concavity indices of streams arguably in a near steady state presented in the literature, which typically range between 0.4 and 0.7 (Whipple, 2004). High concavity index values typically correspond to smooth and concave profiles, while low concavity index values are common in profiles with local convexities related to lithologic knickpoints/knickzones or in profiles subjected to adjustment owing to a persistent forcing. In the study area, high concavity index values associated with the relict profiles should 

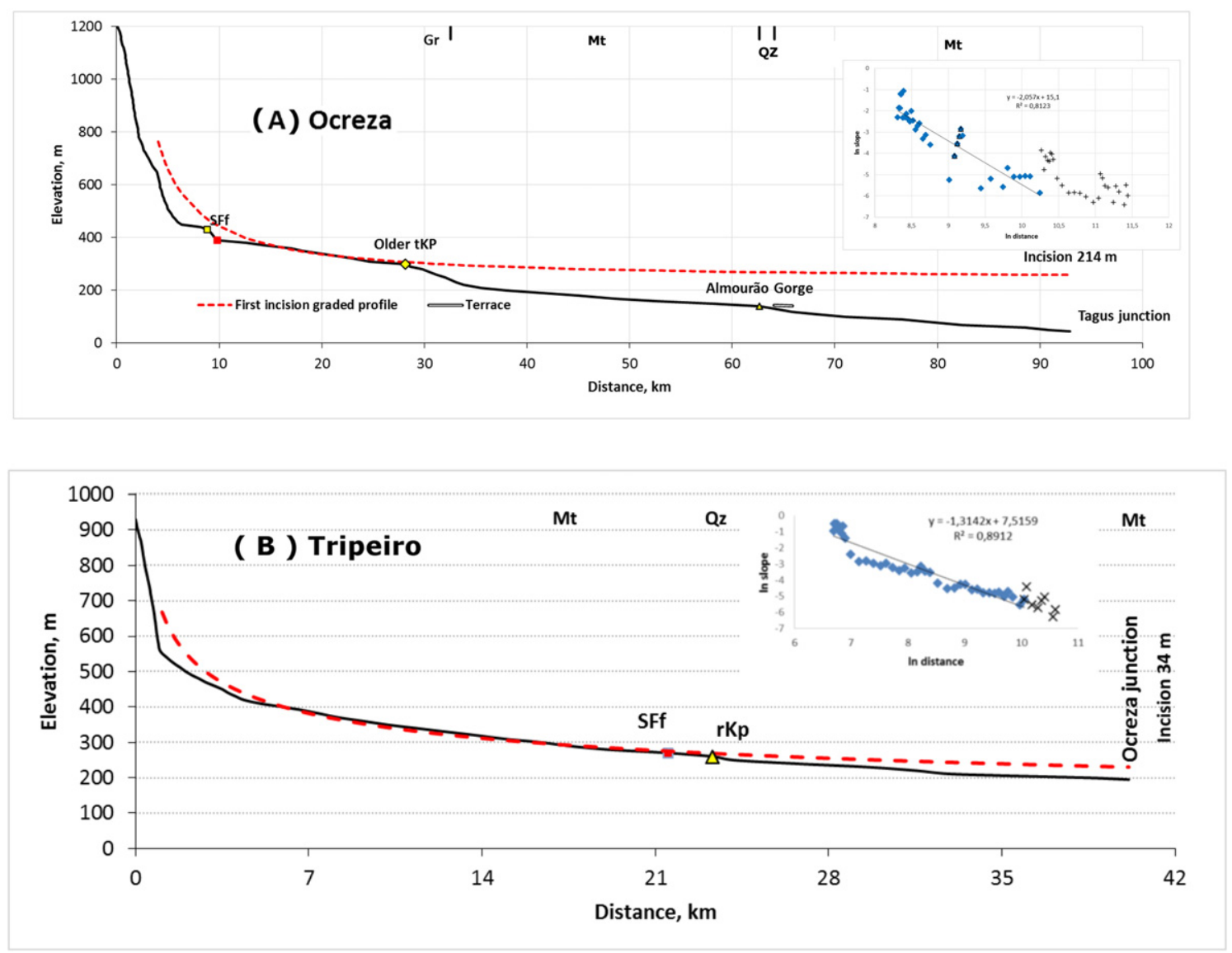

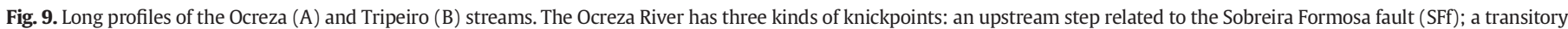

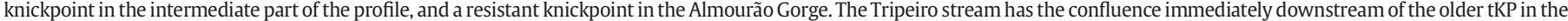
Ocreza River, and this explains the fact that its relict graded profile almost fits the present river profile.

be regarded as representative of a steady state graded profile, generally resulting from a long-lived evolutionary phase in which the rivers were adjusted to a regional base level higher than the current one.

The rejuvenated profiles display a higher $k_{s n}$ index (Table 4; Fig. 13A, $\mathrm{B}, \mathrm{C})$, related to an abrupt change in the surrounding relief topography when compared to the landscape associated with the upstream relict graded profiles. This adjustment affects all streams and has regional significance, as it is also characteristic of other fluvial systems of mainland Portugal and the Spanish border regions (e.g., Antón et al., 2012, 2014). The period of adjustment between the initial disturbance and the final steady state is usually long, $10^{4}$ to $10^{6}$ years (Whipple and Tucker, 1999; Whipple, 2001; Baldwin et al., 2003).

Channel reaches with different channel steepness are readily recognized in the three maps of Fig. 13. Some reaches represent local increases in channel gradient (vertical-step knickpoints), others represent a persistent, longitudinal extensive change in channel gradient (slope-break knickpoints). From the maps (Fig. 13), the key points are: (i) the low values of $k_{s n}$ (classes 1 and 2) are upstream of the older transitory knickpoint, associated with the first incised graded profile, especially when this is longitudinally extensive; (ii) the low values of $k_{s n}$ are in stream reaches controlled by fault lines (i.e., reaches of Tamolha and Isna streams over the Sf, Fig. 13A; Forneas, Sarzedinha, and Alvito over the SFf and Avf, Fig. 13B); (iii) low values of $k_{s n}$ are on stream reaches flowing in a tectonic sedimentary basin (i.e., Mangueja, Tripeiro, and Ponsul rivers, Fig. 13B); and (iv) the abrupt increases in channel gradient occur over the quartzite ridges, at the slatesmetagreywakes/granite contact, or at the crossing of the SFf (Fig. 13B and C).

Tectonic forcing with increases in uplift rate produces a higher efficiency in fluvial incision (Whipple, 2001). The higher normalized steepness index of the rejuvenated profiles associated with the dissected landscape and relief increase, compared with those of the relict profiles (Table 4), is considered to relate to a disturbance of the equilibrium relict profiles, forced by an intensification of the regional uplift during the Quaternary. A coeval adjustment of the drainage to a long-term eustatic sea level lower than that to which the relict profiles were adjusted could also be considered as an additional forcing mechanism.

In spite of the large uncertainties involved, projection of the relict profiles down to the stream mouth provides quite distinct incision values for the different streams. In this discussion we do not consider the streams located at the SE slope of the PCR because for most of these streams the maximum incision could not be calculated (Table 2) for reasons already outlined. It is important to note that the preserved remnants of the relict graded reaches, located headward of the older transitory knickpoints (older tKPs), continued to lower until the present, though at a very small rate owing to their quasi-steady state (Kirby and Whipple, 2012). The rejuvenation of incision inferred by projecting the relict profiles until the stream mouth is thus smaller than it was originally because some lowering of the relict long profiles has occurred since they were developed, hence leading to an underestimation of the regional uplift.

In the Ródão area (Fig. 2), located on the SPPS, an incision can be calculated for the Tagus River using as reference the oldest terrace (T1) at 114 to $180 \mathrm{~m}$ elevation above the river bed, which records the first aggradation episode in the incision stage, giving an incision rate of 0.13 to $0.20 \mathrm{~mm} / \mathrm{y}$. For the studied streams located on the SPPS, the projection of the relict profiles reveals values of incision of ca. $200 \mathrm{~m}$ (Ocreza, Sever, Nisa, and Figueiró). However, there are three exceptions: the Alpreade/Ponsul streams (ca. $150 \mathrm{~m}$ ), the Canas stream (ca. $110 \mathrm{~m}$ ), and the Pracana stream (ca. $120 \mathrm{~m}$ ). One explanation is that they flow 

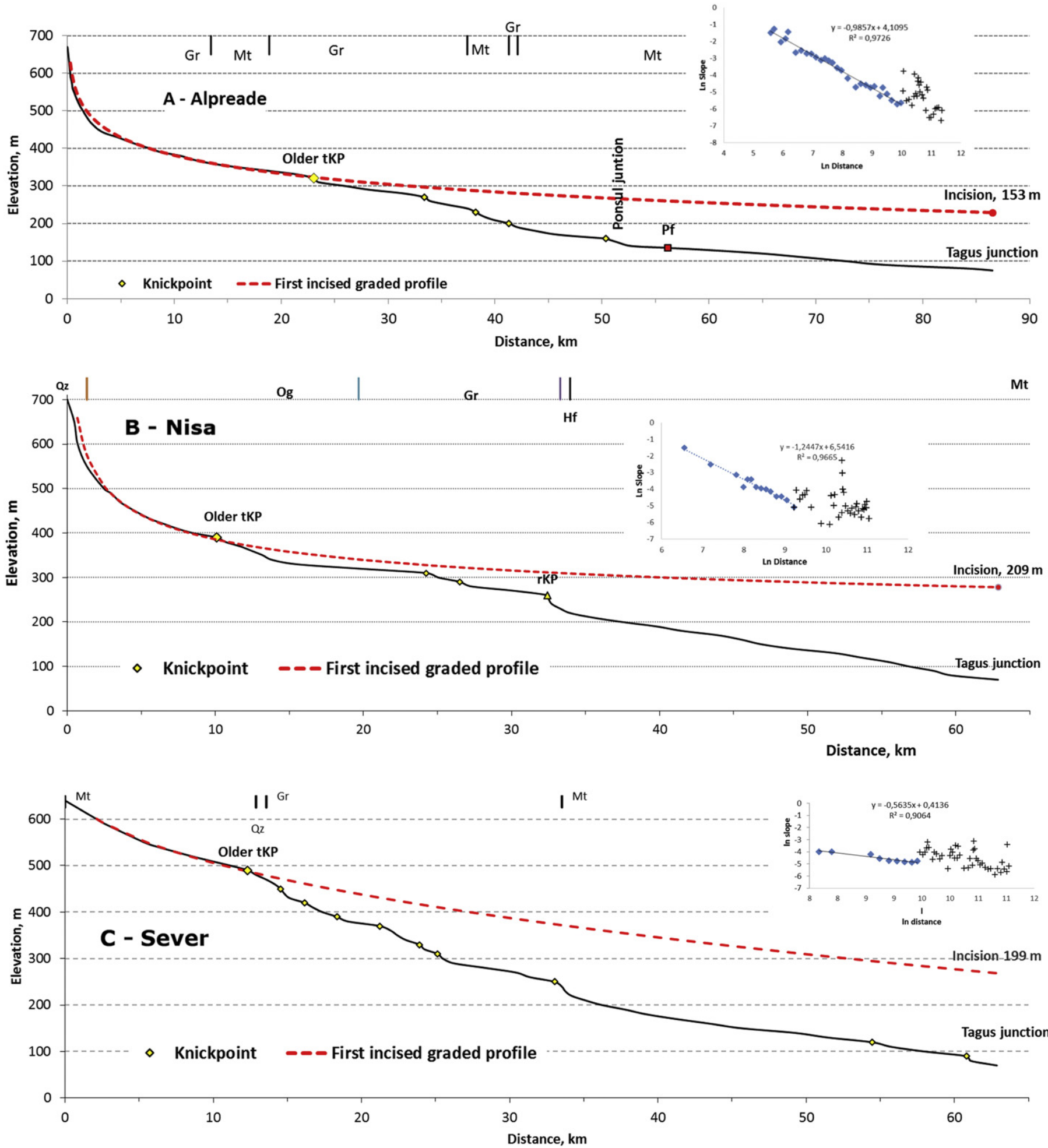

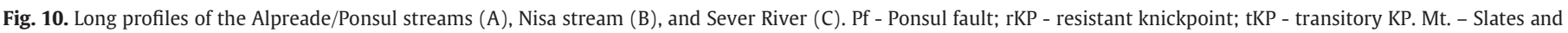

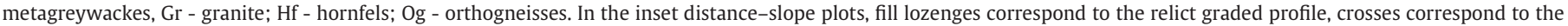
rejuvenated profile located downstream of the older transitory knickpoint (tKP).

in less uplifted areas (Daveau, 1985; Martins, 1999). The incision values of streams flowing in the PCR (Sertã, ca. 150 m; Tamolha, ca. 280 m; Isna, ca. $380 \mathrm{~m}$ ) should not be directly compared with the incision of the streams located on the SPPS because the downstream projections used different trunk rivers: the Zêzere and Tagus, respectively. However, for the same group, the values of incision are higher in the streams flowing through the more uplifted areas, as would be expected.
Despite the absence of geochronological data that could directly date the relict graded profiles studied here, they can be correlated with other geomorphic references documented in the region. The culminant fluvial surface found in the headwaters of the Sertã stream (Fig. 3) and along the Tagus River is coeval with the surface of the culminant sedimentary unit of the Lower Tagus Cenozoic basin, represented by the Falagueira Formation, considered to record the drainage during the Piacenzian to 

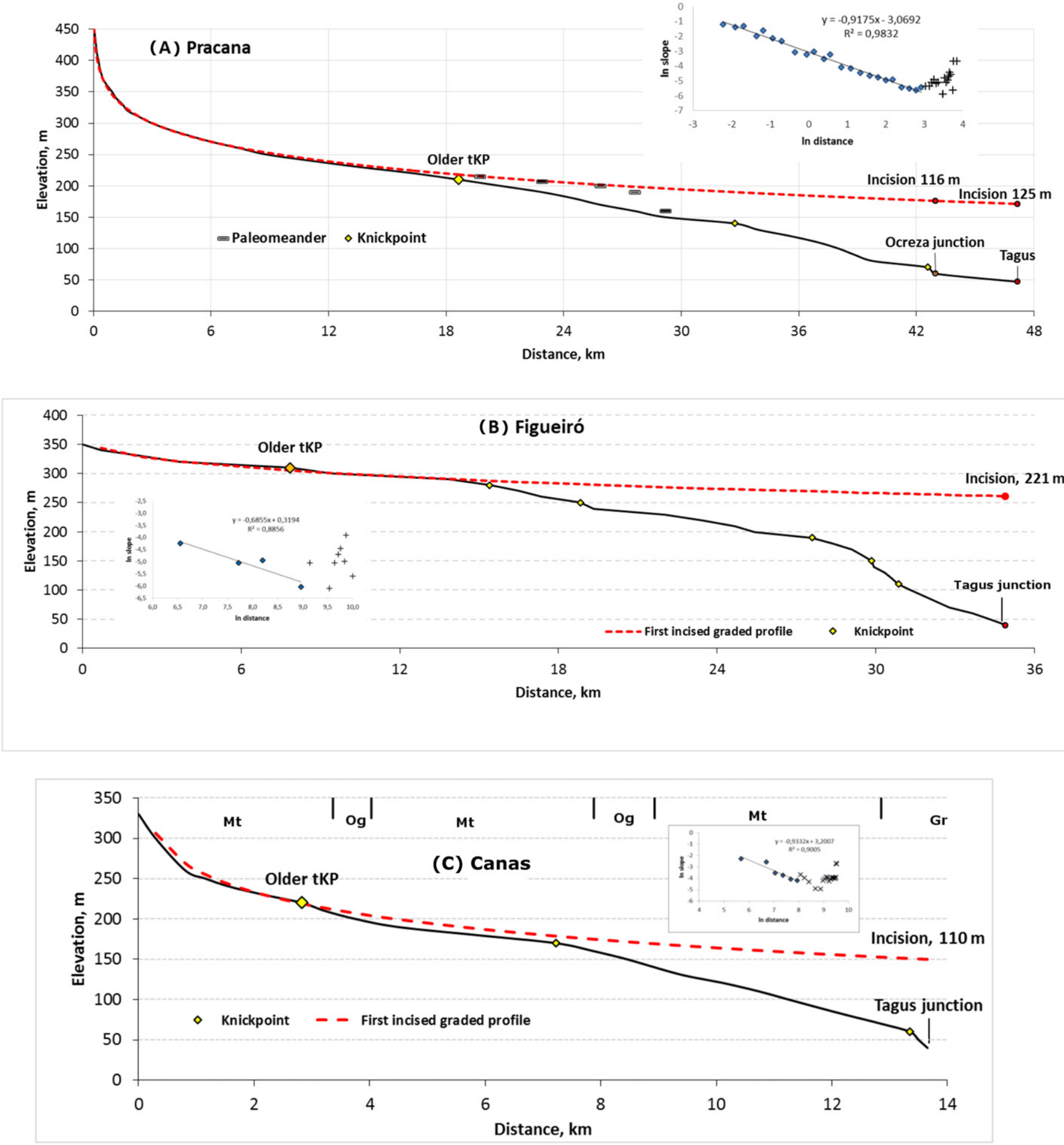

Fig. 11. Long profiles of the Pracana (A), Figueiró (B), and Canas (C) streams.

Gelasian time, ca. 3.6 to 1.8 My (Cunha, 1992, 1996; Cunha et al., 1993, 2009, 2012, 2016; Pais et al., 2012).

The first relict incised graded profile, which is incised into the previous relict culminant fluvial surface, should correlate with the oldest terrace level (T1) of the Tagus and Zêzere rivers, estimated to have an age of ca. 1.1-0.9 My by ESR and OSL dating of the terrace staircase (Cunha et al., 2012, 2016; Rosina et al., 2014; Martins et al., 2010a, 2010b, 2015). This terrace level is largely developed in the Lower Tagus valley area and headward, indicating that it corresponds to a long period of base-level stability, thus providing the necessary conditions for the development of graded profiles along the tributary rivers. The T1 terrace is positioned at 114 to $180 \mathrm{~m}$ above the present Tagus River bed (a.r.b.) in the Ródão depression (Fig. 2). Near the Spanish border, the T1 terrace of the Tagus River is at ca. $190 \mathrm{~m}$ a.r.b., where the Sever River has a similar maximum incision value (Fig. 10C; ca. $200 \mathrm{~m}$ ). Furthermore, the projected relict profiles of the Figueiró, Nisa, and Freixiada streams and of the Ocreza River have approximately the same elevation above the Tagus River bed, also supporting the proposed correlation. 


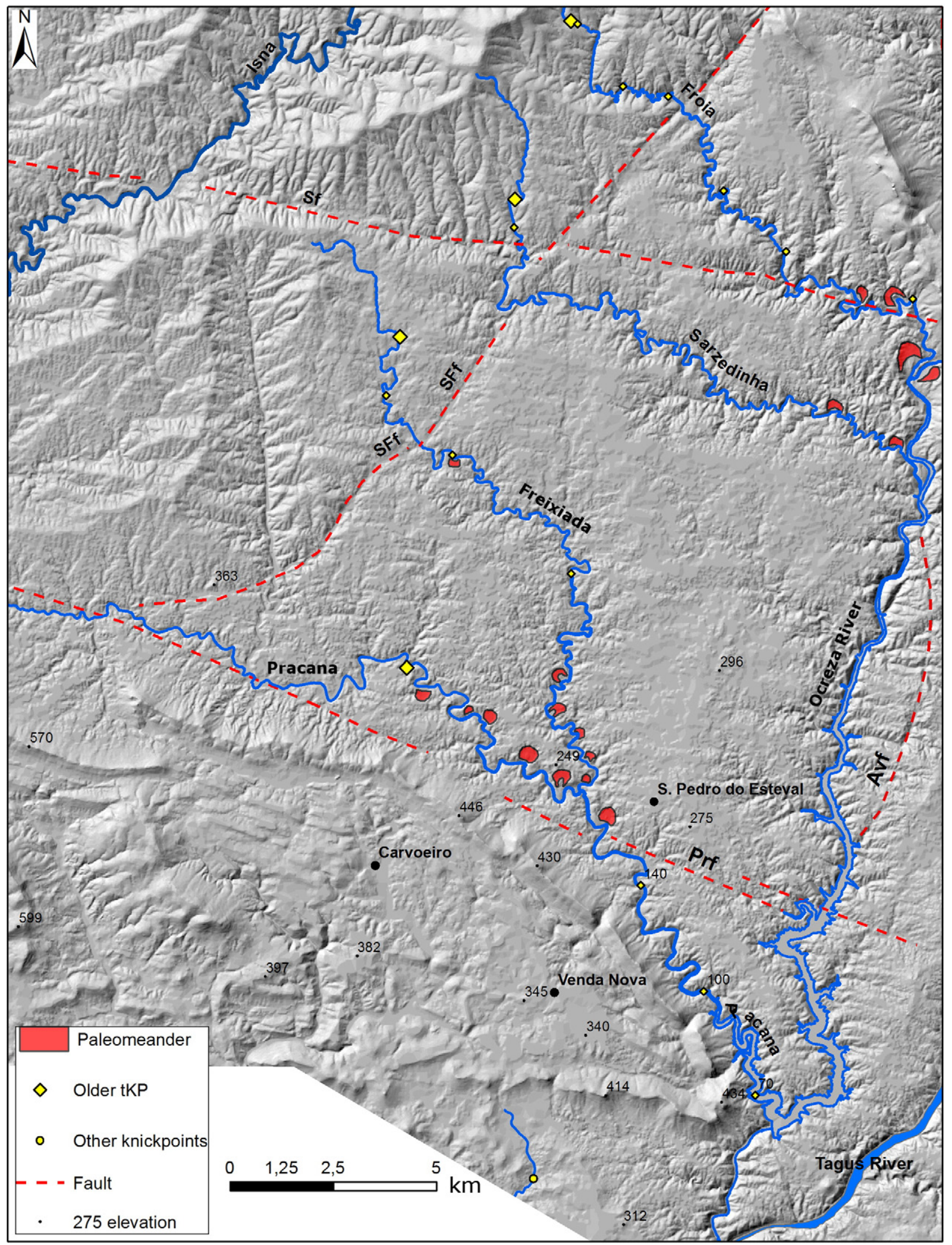

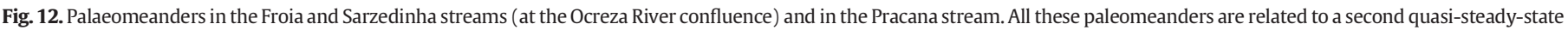

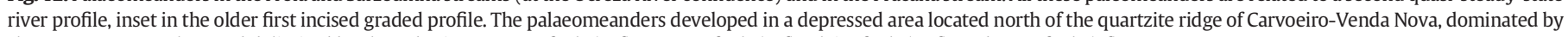
slates/metagreywackes, and delimited by the Sobreira Formosa fault (SFf), Pracana fault (Prf), Alvito fault (Avf), and Sertã fault (Sf).

By assuming that the relict profiles correlate with the T1 terrace of the Tagus River (ca. 1.1-0.9 My), the following average incision rates can be estimated: (i) $0.38 \mathrm{~m} / \mathrm{ky}$ ( $380 \mathrm{~m} / 1 \mathrm{My}$ ) to $0.15 \mathrm{~m} / \mathrm{ky}$ ( $150 \mathrm{~m} /$
$1 \mathrm{My}$ ), for the studied streams located in sectors of the PCR; (ii) $0.22 \mathrm{~m} / \mathrm{ky}(220 \mathrm{~m} / 1 \mathrm{My})$ to $0.12 \mathrm{~m} / \mathrm{ky}(120 \mathrm{~m} / 1 \mathrm{My})$, for the streams flowing on the SPPS. 

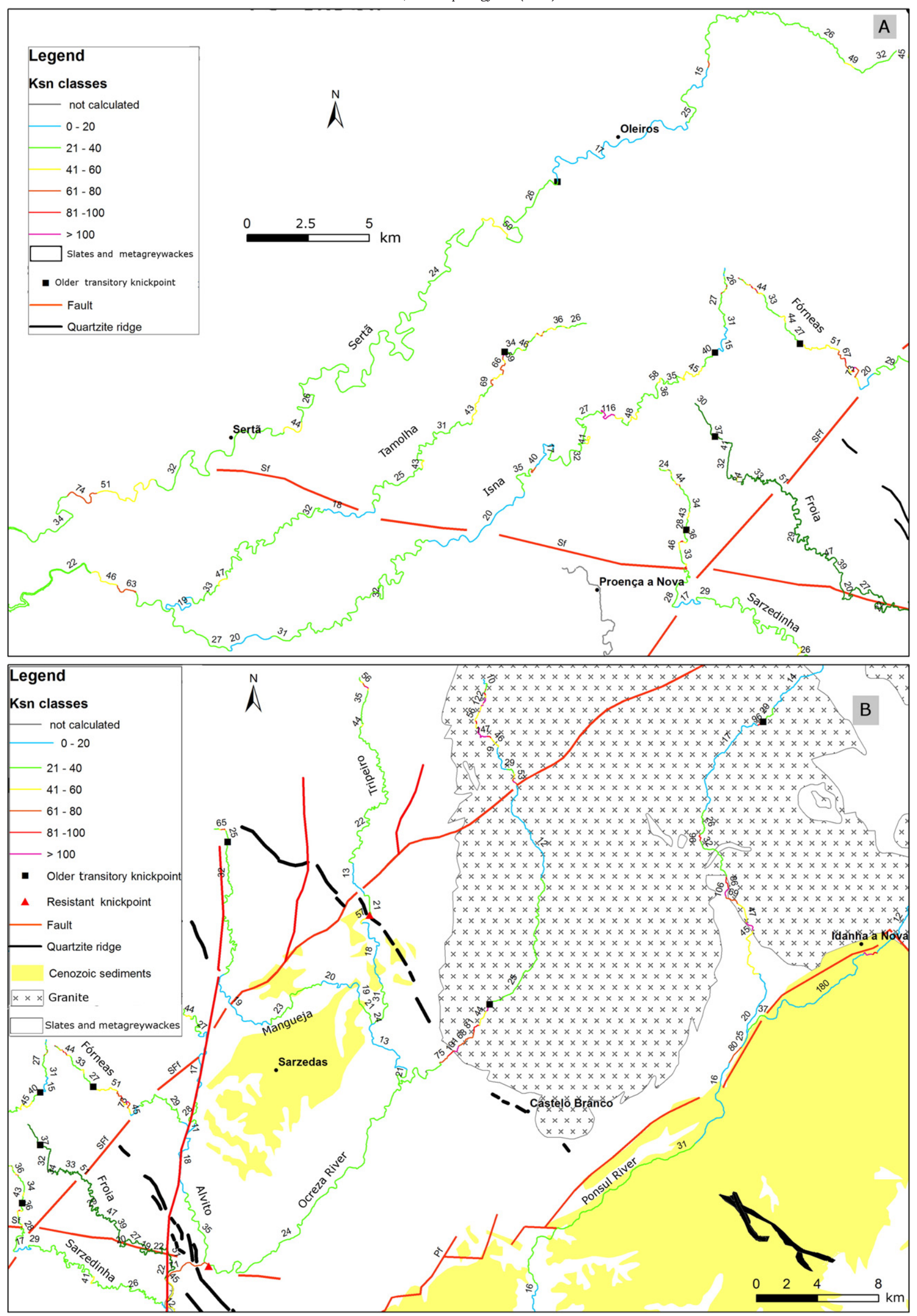

Fig. 13. $k_{s n}$ classes for the studied streams. (A) NW sector of the study area; (B) NE sector of the study area; (C) SW sector of the study area. 


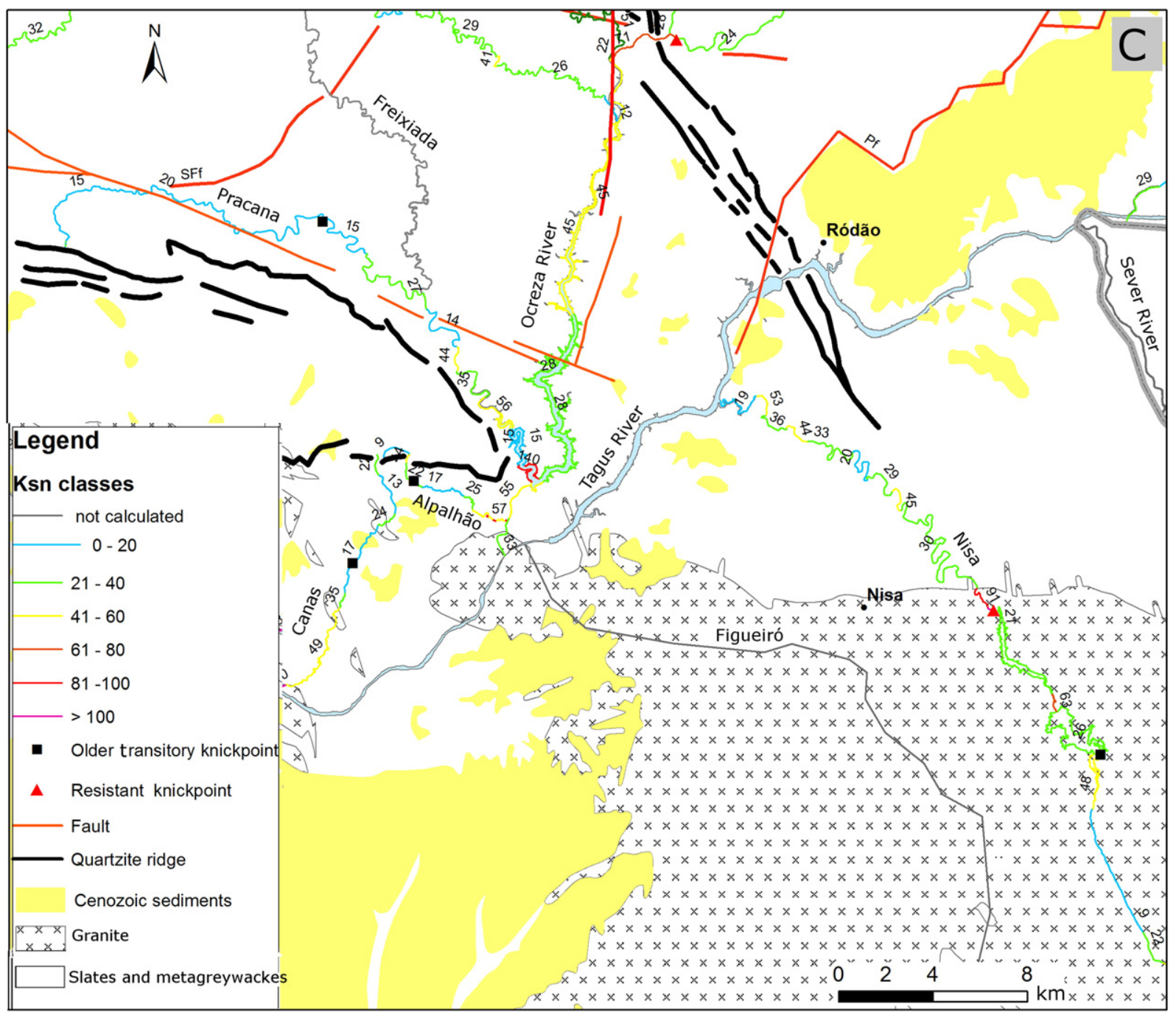

Fig. 13 (continued).

\section{Conclusions}

In central eastern Portugal mainland, the long profiles of tributaries of the Tagus and Zêzere rivers recorded a series of transitory and permanent knickpoints. The permanent knickpoints have direct correlation with the bedrock strength, corresponding to the outcropping of very hard quartzites or to the transition from less resistant (slates/ metagreywackes) to harder (granite) basement.

Most of the analyzed streams record an older transitory knickpoint/ knickzone separating an upstream relict graded reach, with lower steepness and higher concavity (concavity index values of 0.33-0.84), which reflects a long period of quasi-equilibrium conditions attained after the start of the incision stage, from a downstream reach displaying a rejuvenated long profile. This rejuvenated reach shows a steeper gradient and lower concavity, particularly the final segment which is even convex in many streams, testifying to the upstream propagation of incision waves that are the response of each fluvial system to continuous crustal uplift superposed on base-level lowering by the trunk drainages because of a coeval drop of sea level.

During long-lasting conditions of dynamic equilibrium in a stream, a graded profile develops and propagates upstream. Those conditions of dynamic equilibrium between the forcing mechanisms (tectonics, eustasy, and climate) also lead to an enlargement of the valley (by meandering) and to the genesis of a strath.
Downstream of the older transitory knickpoint/knickzone, the long profiles of several studied tributaries (e.g., Sertã, Freixiada, Figueiró, and Canas streams) show several graded reaches separated by knickpoints. This leads to the interpretation that for these streams the stage of general incision was an alternation of dominant periods of degradation (channel downcutting) and periods of quasi-equilibrium conditions (valley floor enlargement) that should correlate with terrace level development on their downstream trunk rivers.

In the present study, the normalized steepness index proved to be sensitive to active tectonics, where lower $k_{s n}$ values were found in relict graded profiles of streams located in less uplifted blocks, namely the Sertã, Pracana, and Canas streams and the lower reach of the Tripeiro, Mangueija, and Ponsul streams $\left(k_{s n}<30\right)$, the latter three flowing through tectonic depressions. The $k_{s n}$ parameter also reveals to be sensitive to lithology, as higher values were found associated with hard basement bedrock (quartzite and granite).

The fluvial incision values obtained from the same relict graded profile identified in each of the studied streams can be used to identify different uplifting blocks and to infer their associated active faults. The incision values of streams flowing in uplifted blocks of the PCR (ca. $380-150 \mathrm{~m}$ ) indicate differential uplift in which they are generally higher than the incision values of streams flowing on the SPPS (ca. $220-120 \mathrm{~m}$ ). The differential uplift indicated by the distribution of the $k_{s n}$ values and by the fluvial incision quantification was likely 
accumulated on several major faults, such as the Sobreira Formosa fault (SFf), thus corroborating the tectonic activity of these faults.

Because the relict graded profiles can be correlated with other geomorphic references documented in the study area, namely the T1 terrace of the Tagus River (with an age of ca. $1 \mathrm{My}$ ), the following incision rates can be estimated: (i) for the studied streams located in uplifted blocks of the PCR, 0.38 to $0.15 \mathrm{~mm} / \mathrm{y}$; and (ii) for the streams flowing on the SPPS, 0.22 to $0.12 \mathrm{~mm} / \mathrm{y}$.

\section{Acknowledgments}

This study was supported by the Fundação para a Ciência e a Tecnologia, through projects PTDC/GEO-GEO/2860/2012 (FASTLOAD), UID/GEO/04683/2013 - ICT, UID/GEO/50019/2013 - IDL, and UID/ MAR/04292/2013 - MARE. The authors wish to thank two anonymous reviewers, and the Co-Editor-in-Chief (Richard A. Marston), for the very constructive comments and suggestions that greatly improved the manuscript.

\section{References}

Antón, L., Rodés, A., De Vicente, G., Pallàs, R., Garcia-Castellanos, D., Stuart, F.M., Braucher R., Bourlès, D., 2012. Quantification of fluvial incision in the Duero Basin (NW Iberia) from longitudinal profile analysis and terrestrial cosmogenic nuclide concentrations. Geomorphology 165-166, 50-61.

Antón, L., De Vicente, G., Muñoz-Martín, A., Stokes, M., 2014. Using river long profiles and geomorphic indices to evaluate the geomorphological signature of continental scale drainage capture, Duero basin (NW Iberia). Geomorphology 206, 240-251.

Baldwin, J.A., Whipple, K.W., Tucker, G.E., 2003. Implications of the shear stress river incision model for the timescale of post-orogenic decay of topography. J. Geophys. Res. 108 (B3). http://dx.doi.org/10.1029/2001JB000550.

Bishop, P., Goldrick, G., 2000. Geomorphological evolution of East Australian continental margin. In: Summerfield, M.A. (Ed.), Geomorphology and Global Tectonics. Willey, Chichester, pp. 225-254.

Cabral, J., 1995. Neotectónica de Portugal continental. Memórias do Instituto Geológico e Mineiro Portugal 31 (265 p).

Cabral, J., 2012. Neotectonics of mainland Portugal: state of the art and future perspectives. J. Iber. Geol. 38, 71-84.

Cabral, J., Ribeiro, A., 1993. Movimentos neotectónicos verticais em Portugal continental, Proceedings 3a Reunião do Quaternário Ibérico, 31-37.

Calais, E., Vergnolle, M., San'kov, V., Lukhnev, A., Miroshnitchenko, A., Amarjargal, S., Déverchère, J., 2003. GPS measurements of crustal deformation in the Baikal-Mongolia area (1994-2002): implications for current kinematics of Asia. J. Geophys. Res. 108 (B10), 2501. http://dx.doi.org/10.1029/2002JB002373.

Carvalhido, R.P., Pereira, D.I., Cunha, P.P., Buylaert, J.-P., Murray, A.S., 2014. Characterization and dating of coastal deposits of NW Portugal (Minho-Neiva area): a record of climate, eustasy and crustal uplift during the quaternary. Quat. Int. 328-329, 94-106.

Cloetingh, S., Burov, E., Beekman, F., Andeweg, B., Andriessen, P.A.M., Garcia-Castellanos, D., De Vicente, G., Vegas, R., 2002. Lithospheric folding in Iberia. Tectonics 21 (5), 1041-1067.

Cloetingh, S., Ziegler, P., Beekman, F., Andriessen, P., Matenco, L., Bada, G., GarciaCastellanos, D., Hardebol, N., Dèzes, P., Sokoutisa, D., 2005. Lithospheric memory, state of stress andrheology: neotectonic controls on Europe's intraplate continental topography. Quat. Sci. Rev. 24, 241-304.

Crosby, B.T., Whipple, K.X., 2006. Knickpoint initiation and distribution within fluvial networks: 236 waterfalls in the Waipaoa River, North Island, New Zealand. Geomorphology $82,16-38$.

Cunha, P.P., 1987. Evolução tectono-sedimentar terciária da região de Sarzedas (Portugal). Comun. Serv. Geol. Portugal 73 (1/2), 67-84.

Cunha, P.P. 1992. Estratigrafia e sedimentologia dos depósitos do Cretácico Superior e Terciário de Portugal Central, a leste de Coimbra. PhD Thesis. Universidade de Coimbra, Portugal (262 pp).

Cunha, P.P., 1996. Unidades litostratigráficas do Terciário da Beira Baixa (Portugal). Comum. Instituto Geol. Mineiro 82, 87-130.

Cunha, P.P., Pena dos Reis, R., 1995. Cretaceous sedimentary and tectonic evolution of the northern sector of the Lusitanian Basin. Cretac. Res. 16, 155-170.

Cunha, P.P., Barbosa, B.P., Pena dos Reis, R., 1993. Synthesis of the Piacenzian onshore record, between the Aveiro and Setúbal parallels (Western Portuguese margin). Ciências da Terra (Univ. Nova de Lisboa). 12, pp. 35-43.

Cunha, P., Martins, A.A., Daveau, S., Friend, P., 2005. Tectonic control of the Tejo river fluvial incision during the late Cenozoic, in Ródão - central Portugal (Atlantic Iberian border). Geomorphology 64, 271-298.

Cunha, P.P., Martins, A.A., Huot, S., Murray, A., Raposo, L., 2008. Dating the Tejo River lower terraces in the Ródão area (Portugal) to assess the role of tectonics and uplift. Geomorphology 102, 43-54.

Cunha, P.P., Pais, J., Legoinha, P., 2009. Evolução geológica de Portugal Continental durante o Cenozóico, sedimentação aluvial e marinha numa margem continental passiva (Ibéria ocidental). Proceedings $6^{\circ}$ Simpósio sobre el Margem Ibérico Atlántico MIA09, pp. 11-20.
Cunha, P.P., Almeida, N., Aubry, T., Martins, A.A., Murray, S.A., Buylaert, J.-P., Sohbati, R, Raposo, L., Rocha, L., 2012. Records of human occupation from Pleistocene river terrace and aeolian sediments in the Arneiro depression (Lower Tejo River, central eastern Portugal). Geomorphology 165-166, 78-90. http://dx.doi.org/10.1016/j. geomorph.2012.02.017.

Cunha, P.P., Martins, A.A., Gouveia, M.P., 2016. The terrace staircases of the Lower Tagus River (Ródão to Chamusca) - characterization and interpretation of the sedimentary, tectonic, climatic and Palaeolithic data. Estudos do Quaternário/Quaternary Studies $14,1-24$.

Daveau, S., 1985. Critères géomorphologiques de déformations tectoniques récentes dans les montagnes de schistes de la Cordilheira Central (Portugal). Bulletin de l'Association française pour l'étude du Quaternaire 4, 229-238.

Daveau, S., Birot, P., Ribeiro, O., 1985-1986. Les Bassins de Lousã et D'Arganil, Recherches Géomorphologiques et Sedimentologiques sur le Massif Ancien et la Couverture à L'Est de Coimbra. Mem. Cent. Est. Geogr. 8 Vol. II 450 pp.

De Vicente, G., Vegas, R., Muñoz-Martín, A., Silva, P.G., Andriessen, P., Cloetingh, S. González-Casado, J.M., Van Wees, J.D., Álvarez, J., Carbó, A., Olaiz, A., 2007. Cenozoic thick-skinned and topography evolution of the Spanish central system. Glob. Planet. Chang. 58, 335-381.

De Vicente, G., Cloetingh, S., Muñoz-Martín, A., Olaiz, A., Stich, D., Vegas, R., GalindoZaldivar, J., Fernández-Lozano, J., 2008. Inversion of moment tensor focal mechanisms for active stresses around microcontinent Iberia: tectonic implications. Tectonics 27, $1-22$.

De Vicente, G., Cloetingh, S., Van Wees, J.D., Cunha, P.P., 2011. Tectonic classification of Cenozoic Iberian foreland basins. Tectonophysics 502 (1-2), 38-61.

Dias, R.P., Cabral, J., 1989. Neogene and quaternary reactivation of the Ponsul river fault in Portugal. Commun. Serv. Geol. Port. 75, 3-28.

Dinis, J., Rey, J., Cunha, P.P., Callapez, P., Pena dos Reis, R., 2008. Stratigraphy and allogenic controls of the western Portugal Cretaceous: an updated synthesis. Cretac. Res. 29, 772-780.

Diniz, F., Silva, C.M., Cachão, M., 2016. O Pliocénico de Pombal (Bacia do Mondego, Portugal Oeste): biostratigrafia, paleoecologia e paleobiogeografia. Estudos do Quaternário/Quaternary Studies 14, 41-59.

Fernandes, R.M.S., Miranda, J.M., Meijninger, B.M.L., Bos, M.S., Noomen, R., Bastos, L., 2007. Surface velocity field of the Ibero-Maghrebian segment of the Eurasia-Nubia plate boundary. Geophys. J. 169 (1), 315-324.

Flint, J.J., 1974. Stream gradient as a function of order, magnitude and discharge. Water Resour. Res. 10, 969-973.

Goldrick, G., Bishop, P., 2007. Regional analysis of bedrock stream long profiles: evaluation of Hack's SL form, and formulation and assessment of an alternative (the DS form). Earth Surf. Process. Landf. 32, 649-671.

Hack, J.T., 1973. Stream-profile analysis and stream-gradient index. J. Res. U.S. Geol. Surv. 1, 421-429.

Howard, A.D., Kerby, G., 1983. Channel changes in badlands. Geol. Soc. Am. Bull. 94 739-752.

Howard, A.D., Dietrich, W.E., Seidl, M.A., 1994. Modeling fluvial erosion on regional to continental scales. J. Geophys. Res. Solid Earth 99 (B7), 13971-13986.

Kirby, E., Whipple, K., 2001. Quantifying differential rock-uplift rates via stream profile analysis. Geology 29 (5), 415-418.

Kirby, E., Whipple, K., 2012. Expression of active tectonics in erosional landscapes. J. Struct. Geol. 44, 54-74.

Kirby, E., Whipple, K., Tang, W., Zhiliang, C., 2003. Distribution of active rock uplift along the eastern margin of the Tibetan plateau: inferences from bedrock channel longitudinal profiles. J. Geophys. Res. 108 (B4), 2217. http://dx.doi.org/10.1029/ 2001JB000861.

Martins, A.A., 1999. Caracterização morfotectónica e morfossedimentar da Bacia do Baixo Tejo (Pliocénico e Quaternário). PhD Thesis. Univ. Évora (500 p).

Martins, A.A., Cunha, P.P., Huot, S., Murray, A.S., Buylaert, J.-P., 2009. Geomorphological correlation of the tectonically displaced Tejo River terraces (Gavião-Chamusca area, central Portugal) supported by luminescence dating. Quat. Int. 199, 75-91.

Martins, A.A., Cunha, P.P., Buylaert, J.-P., Huot, S., Murray, A.S., Dinis, P., Stokes, M., 2010a K-feldspar IRSL dating of a Pleistocene river terrace sequence of the Lower Tejo River (Portugal, western Iberia). Quat. Geochronol. 5, 176-180.

Martins, A. A Cunha, P.P. Rosina, P. Oosterbeck, L, Cura, S., Grimaldi, S., Gomes, J. Buylaert, J.-P., Murray, A.S., Matos, J., 2010b. Geoarchaeology of Pleistocene open air sites in the Vila Nova da Barquinha - Santa Cita area (Lower Tejo River basin, central Portugal). Proc. Geol. Assoc. 121, 128-140.

Martins, A.A., Cunha, P.P., Paiva, A., Cabral, J., Stokes, M., 2015. Geomorphological cartography on the River Tejo lower valley - implications for interpretation of landscape and environmental changes of western Iberia in the last 2 Ma. Progress in Quaternary archive studies in the Iberian Peninsula (Proceedings), Seville (Spain), pp. 75-76.

Montgomery, D., Dietrich, W., 1988. Where do channels begin? Nature 336, 232-234. http://dx.doi.org/10.1038/336232a0

Montgomery, D.R., Foufoula-Georgiou, E., 1993. Channel network source representation using digital elevation models. Water Resour. Res. 29, 3925-3934.

Nocquet, J., Calais, E., 2004. Geodetic measurements of crustal deformation in the Western Mediterranean and Europe. Pure Appl. Geophys. 161, 661-681. http://dx.doi.org/10 1007/s00024-003-2468-z.

Pais, J., Cunha, P.P., Pereira, D., Legoinha, P., Dias, R., Moura, D., Brum da Silveira, A Kullberg, J.C., González-Delgado, J.A., 2012. The Paleogene and Neogene of Western Iberia (Portugal). A Cenozoic record in the European Atlantic domain. SpringerBriefs in Earth Sciences. 1 vol. Springer (Series ID: 8897). 158 pp.

Pérez-González, A., 1994. Depresión del Tajo. In: Gutiérrez-Elorza, M. (Ed.), Geomorfologia de España. Editorial Rueda (389-436 pp).

Ramos, A., Cunha, P.P., Cunha, L., Gomes, A., Lopes, F.C., Buylaert, J.-P., Murray, A.S., 2012 The river Mondego terraces at the Figueira da Foz coastal area (western central 
Portugal): geomorphological and sedimentological characterization of a terrace staircase affected by differential uplift and glacio-eustasy. Geomorphology 165-166, 107-123.

Ribeiro, O., 1942. Notas sobre a evolução morfológica da orla meridional da Cordilheira Central entre Sobreira Formosa e a Fronteira. I(3). Boletim da Sociedade Geológica de Portugal, pp. 123-144.

Ribeiro, A., 1984. Néotectonique du Portugal. Livro de Homenagem a Orlando Ribeiro. Centro de Estudos Geográficos de Lisboa, pp. 173-182.

Ribeiro, A., Kullberg, M.C., Kullberg, J.C., Manuppella, G., Phipps, S., 1990. A review of alpine tectonics in Portugal: foreland detachment in basement and cover rocks. Tectonophysics 184, 357-366.

Ribeiro, A., Cabral, J., Baptista, R., Matias, L., 1996. Stress pattern in Portugal mainland and adjacent Atlantic region, West Iberia. Tectonics 15 (2), 642-659.

Rosina, P., Voinchet, P., Bahain, J., Cristovão, J., Falguères, C., 2014. Dating the onset of Lower Tagus River terrace formation using electron spin resonance. J. Quat. Sci. 29 (2), 153-162.

Sequeira, A., Cunha, P.P., Sousa, M.B., 1997. A reactivação de falhas, no intenso contexto compressivo desde meados do Tortoniano, na região de Espinhal-Coja-Caramulo (Portugal Central). Comun. Inst. Geol. e Mineiro 83, 95-126.

Snyder, N., Whipple, K., Tucker, G., Merritts, D., 2000. Landscape response to tectonic forcing: DEM analysis of stream profiles in the Mendocino triple junction region, northern California. Geol. Soc. Am. Bull. 112, 1250-1263.
Vegas, R., 2005. Deformación alpina de macizos antiguos. El caso del Macizo Ibérico (Hespérico). Bol. R. Soc. Hist. Nat. (Sec. Geol.) 100 (1-4), 39-54.

Vegas, R., 2006. Modelo tectónico de formación de los relieves montañosos y las cuencas de sedimentación terciarias del interior de la Península Ibérica. Bol. R. Soc. Esp. Hist. Nat. Sec. Geol. 101 (1-4), 31-40.

Whipple, K.X., 2001. Fluvial landscape response time: how plausible is steady state denudation? Am. J. Sci. 301, 313-325.

Whipple, K.X., 2004. Bedrock rivers and the geomorphology of active orogens. Annu. Rev. Earth Planet. Sci. 32, 151-185.

Whipple, K.X., Tucker, G.E., 1999. Dynamics of the stream-power river incision model; implications for height limits of mountain ranges, landscape response timescales, and research needs. J. Geophys. Res. Solid Earth 104 (B8), 17661-17674.

Whipple, K.X., DiBiase, R.A., Crosby, B.T., 2013. Bedrock rivers. In: Shroder, J., Wohl, E. (Eds.), Treatise on GeomorphologyFluvial Geomorphology vol. 9. Academic Press, San Diego, CA, pp. 550-573.

Wobus, C.W., Whipple, K.X., Kirby, E., Snyder, N.P., Johnson, J., Spyropolou, K., Crosby, B.T., Sheehan, D., 2006. Tectonics from topography: Procedures, promise and pitfalls. In: Willett, S.D., Hovius, N., Brandon, M.T., Fisher, D.M. (Eds.), Tectonics, Climate and Landscape Evolution: Geological Society of America Special Paper 398. Penrose Conference Series, pp. 55-74. 